\title{
A Study of Peculiar and Exceptional Children
}

\section{E. W. Bohannon}

To cite this article: E. W. Bohannon (1896) A Study of Peculiar and Exceptional Children, The Pedagogical Seminary, 4:1, 3-60, DOI: 10.1080/08919402.1896.10532955

To link to this article: http://dx.doi.org/10.1080/08919402.1896.10532955

册 Published online: 28 Aug 2012.

Submit your article to this journal 2

III Article views: 40

Q View related articles $\asymp$

Citing articles: 1 View citing articles ¿ 


\section{A STUDY OF PECULIAR AND EXCEPTIONAL CHILDREN.}

By E. W. Bohannow, Fellow in Pedagogy, Clark University.

\section{INTRODUCTION.}

The basis of the present study is a collection of reports received in response to the syllabus printed below.

\section{PECULIAR AND EXCEPTIONAL CHILDREN.}

If you desire to receive the syllabi of this school year, to co-operate in collecting data, and to receive the final reports of the work, you are hereby respectfully invited :

I. To think over your own childhood and consider if you were a striking illustration of any of the following types, and if so, describe your case.

II. Consider if you have any friends who would come into any of the classes below, and ask them to describe their own case.

III. If you have children of your own, or if you are a teacher, if any of your pupils, past or present, are strikingly exceptional, describe them.

IV. If you are a college or normal instructor, explain very fully what is wanted, and ask each pupil to describe one or more such cases in a composition, essay, or a theme in psychology.

V. State the salient points concerning any exceptional children you ever read of, whether fact or fiction, referring to the source if you can.

The following are types suggested to select from, but any others will be welcome :

1. Physical: Exceptional beauty or ugliness; largeness or smallness; any bodily deformity; conspicuous scars or tranmatic lesions; defects of sense or limb, as dimness of vision or slightly under normai hearing, weakness of spine, legs or arms, etc.; exceptional strength, agility, ciumsiness or deftness, or gifts of sense; any other marked physical peculiarity.

2. Psychical: A child of exceptional courage or timidity ; cleanliness or dirtiness; order or disorder; obedience or disobedience ; truth telling or lying; cruelty or sympathy; selfishness or generosity; loquacity or silence ; frankness or secretiveness ; buoyancy or despondency; daintiness or gluttony; a blasé or otherwise spoiled child; a doubter, investigator or critic; a buffoon; a restless, fickle scatterbrain or a tenacious child; an ugly and ill-tempered child; a careless, easy-going or a fastidious child; an inquisitive, imaginative or poetic 
child; a teaser or hector; a nervous child; a querulent. whining child; a dignified and self.poised clild, or one who acts habitually with abandon.

It is not a description of one or more of the above traits that is wanted, but an account of one or more indiridual cases where one trait or group of traits is so marked as to color the entire character of the child, to be known to all who see much of it, to therefore bear on the child's future career.

Note in each case, if you can, whether the trait is hereditary; in which parent, how far back can it be traced, and how marked was it in the ancestry? To this point the greatest importance is attached, and it should receive special attention.

Give, briefly, specific acts or instances of the manifestation of the trait.

State bow each case has been treated at home and in school, and how you think it should be.

A.lways describe each case with the greatest conciseness and with the greatest fidelity to fact.

Always state age, sex, vationality, complexion and temperament.

Always write on but one side of your paper.

Begin every new case on a new page.

Write at the head of the first page of each case one or more words desiguating the type, as a dirty child, i precocious child, etc.

Send returns to

G. STANLEY Hall,

or E. W. BOHAN NON.

Clark University, Worcester, Mass.. Oct. 17,1895 .

Altogether 1,045 cases were described. About 850 of these came from Miss I,illie A: Williams, of the New Jersey State Normal School at Trenton; about 75 from Pres. Geo. C. Puriugton, of the State Normal School at Farmington, Me.; a like number from Mrs. A. R. Hornbrook, of the Evansville, Ind., High School, and 35 or 40 from personal sources and friends. Every report bears evidence of sincerity, and practically all, of thoughtful, careful preparation. Those from Trenton were prepared under the personal supervision of Miss Williams, and constituted a part of the regular work of her students in psychology. They are of the very highest value. and without them the study could hardly have been made. Grateful acknowledgment is here made to all those who have contributed so largely of their time and energy in answering the questions of the syllabus.

Of the whole number of cases reported $6 r_{3}$ are girls, and 432 are boys. Fourteen of the $t, 045$ reports do not appear in some of the percentages to be presented later, because the number of cases in any of the types which they represent is too small to be of any value in tabulation. Not counting this 14 , and including the group of "Only Children," 43 types are included. The individuals described are of various ages, but nearly all are below the perind of early manhood or woman- 
hood; at least the peculiarity is described as it appeared before that time.

The study was suggested by the manifest need for a more intimate knowledge of the individual life of children. This knowledge depends upon a better understanding of certain biological factors. As Maudsley" has said : "In the outset I make two general assumptions : that a man is what he is at any period of life, first, by virtue of the original qualities which he has received from his ancestors, and, secondly, by virtue of the modifications which have been effected in his original nature by the influence of education and of the conditions of life. But what a complex composition of causes and conditions do these simple statements iniport."

All children are peculiar and exceptional in some degree. Any classification of them is, therefore, in a sense misleading and does violence to the inmost nature. The demand for organization in accordance with scientific principles, however valuable such organization may be in certain respects, seems only to have blinded many to the fact that there is a most vital something in every human being that will not yield to classification. Yet it would be dangerous to forget for a single moment that there are many points of agreement between all individuals. Neither aspect of life may be omitted in the consideration of the other. The purpose is simply to help to a better understanding of, and appreciation for, the peculiar and individual iu the life of the child, that which belongs to one child only and distinguishes from other children. It is not the purpose to determine how far the one or the other of these two lines of growth should be emphasized, nor is it the thought that there is necessarily a conflict between them. Chief among the difficulties which are incident, therefore, to such a study, is the fact that only a limited number of individuals can be studied, and that individuality reveals itself but imperfectly to others.

It is possible to present only a very few (and these in the most condensed form) of the reported cases of the various types. All, however, are taken into account in the tables which appear later. The presentation of data will be followed by its statistical analysis, and such conclusions as seem to be warranted therefrom. The statistics relate especially to the relative inheritance of advantageous and disadvantageous peculiarities, to nationality, and temperament.

1 Maudsley's "Pathology of Mind," p. 87. 


\section{REPORTS ILLUSTRATIVE OF THE TYPES.}

HEAVY.

I. M. 15 yrs. old. Light. Phlegmatic. Grew very large after 13 and is taken to be 20 . Not clumsy or awkward. Good natured, easy, and well liked. Associates with men of 20 and 25. Grandparents large and sinewy.

2. M. 12 yrs. old. Weighs 172 pounds. $4 \mathrm{ft} .7$ ins. tall in stocking feet. Head measured 22 ins., waist 45 , and chest 40 . Well formed and enjoys excellent health. Eats as much as two ordinary men. Has high standing at school. Is ambitious to be a big man. Much noticed, but does not mind it. Father weighs 215 .

3. M. 5 yrs. old. Irish. Weighed 80 lbs, at 4 . Noticed so much that his mother was ashamed to give his age. Mother large.

4. F. 8 yrs. old, weighs too lbs. $4 \mathrm{ft}$. tall. Girls often call her "Mutton Chops," on account of her stoutness. Mother and grandmother quite large.

5. F. I7 yrs. old. Light. As Jarge at 12 as now. Larger at 14 than now. More expected of me at school on account of my size. Father had growth early.

6. F. 16 yrs. old. Dark. Weighed 160 lbs. Made herself proninent. Not sensitive. Father very large. Mother small.

7. F. 11 yrs. old. Nervous. Weighed $\times 50$ lbs. $5 \mathrm{ft} .7$ ins. tall. Brothers and sisters often call her "fatty." This discourages her and frequently causes ber to go into her room and cry. Mother weighs 220, and her father and grandfather are of unusual size.

8. F. 7 yrs. old. Weighed 140 at 5 . Children call her "fatty." This makes her angry and she has becomed impudent. Mother large.

9. F. 12 yrs. old. Light. Weighed go pounds at 6 . Good natured. Called "Baby Jumbo" and "Little 500 pounds." Mother, and her parents large.

Ic. F. 10 yrs, old. Light. Strong and self-willed. Weighed I 10. Is bright and quick. Much noticed. Delights in rough, boyish sports. Would jump on bare-backed horse, put her arms about its neck, her feet against the sides, and sail along the road in great delight.

\section{THE TALL.}

Ir. F. 7 yrs. old. $5 \mathrm{ft}$. tall. Taken to be 14 years old. Thinks it terrible to be so tall. Associates with older girls. Mother tall.

12. F. I3 years old. 5 feet 8 ins. in height. Not allowed to go out with family and kept out of sight as much as possible. Termed a "big, lanky thing." Same treatment at school.

13. F. I5 yrs. old. 5 feet 9 ins. in beight. Grew rapidly. Tallest girl for miles around. Every one remarked on her height. Treated as older than she was. Parents tall.

14. F. 15 yrs. old. $6 \mathrm{ft}$. tall. Looked much older. People ask her "how much longer," "how much taller," etc., she is going to grow. Parents seem to think she ought to know everything because she is large.

15. M. Io yrs. old. Unusually tall and large, taken to be 16 or 18 . Was a coward. Teased. Ancestors large.

\section{STour.}

I6. M. 21 yrs old. Weighs II5 pounds. About $4 \mathrm{ft}$. tall. Conceited. Quick-tempered. Teased a great deal.

17. F. I3 years old. Weighs 104 pounds. Fair. Happy. Joked about her stoutness, but does not seem to mind. Father stout. 
I8. M. 40 yrs. old. Weight 150 pounds. $4 \mathrm{ft}$. tall. Pointed out as curiosity.

The following table gives the average heights and weights of boys and girls, for each year, between the years of eleven and twenty, in seven different countries. These general averages of both sexes for the various years may be relied upon as fairly approximating the average weight of any individual of normal

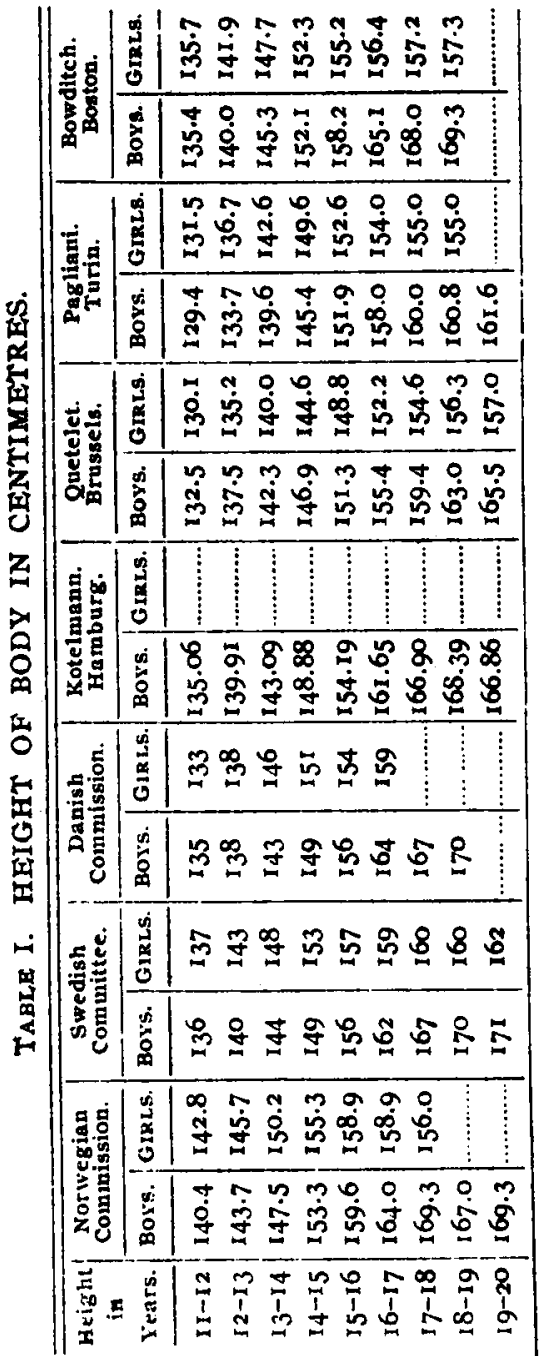

\begin{tabular}{|c|c|}
\hline & 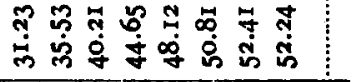 \\
\hline & 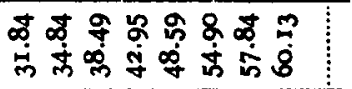 \\
\hline & 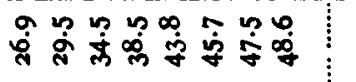 \\
\hline & 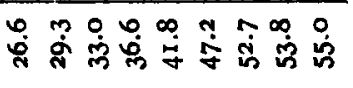 \\
\hline & 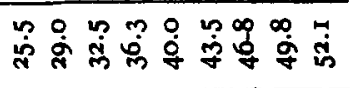 \\
\hline & 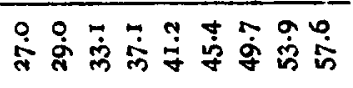 \\
\hline & \begin{tabular}{lllll|l} 
& & $\vdots$ & \\
& $\vdots$ & &
\end{tabular} \\
\hline & 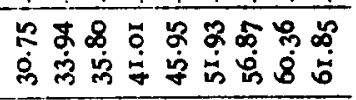 \\
\hline & 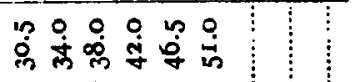 \\
\hline & 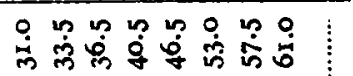 \\
\hline & 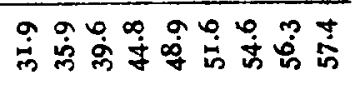 \\
\hline & 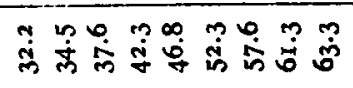 \\
\hline & 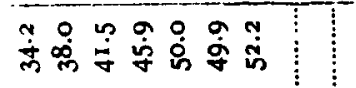 \\
\hline & 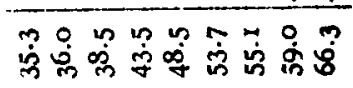 \\
\hline & 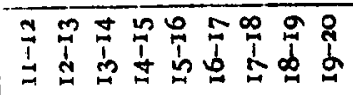 \\
\hline
\end{tabular}


development at corresponding ages, of the different races represented. For example, Bowditch's figures give the normal approximately for American children. The table will be helpful in supplying a standard by means of which it is easy to determine the amount of deviation from the normal in height and weight.

Perhaps the most significant thing to be observed in the reports of the large children-the tall, the heavy, and the stout-is their very general association with older children to escape the undue attention which their size provokes. Quite as general also is the custom of dressing them like their associates. "Was treated according to size and not according to age," " more was expected of me than of others on account of my size," "had to do all the hard and heavy work," etc., are some of the expressions indicating the treatment. The children of this group are therefore made to submit to an unnatural environment, one which certainly has the effect of stimulating to premature development mentally. It seemsquite as reasonable to suppose that the apparently greater maturity of large children is due quite as much to their treatment as to any natural cause.

As to general health and mental ability, there appears to be good reason to believe that the larger children-excepting extremes-are superior to others. But it must not be forgotten that there are pathological cases in this group, and that the extremely exceptional ones show a marked tendency to a pathological condition. The fact that such are extremes should be remembered. The tall seem to be more sensitive about their peculiarity than do the stout and heavy, while the stout show more pathological cases. The result of the treatment which this class receives is therefore a too early maturity. While this is the result of effort to escape undue attention, it seems that it is not very likely to result in a morbid sensitiveness. Other qualities found in such children are good nature, evenness of temperament, and popularity with others.

\section{SMALL.}

I. F. I2 yrs. old. $3 \frac{1}{2} \mathrm{ft}$. tall. Weight 50 pounds. Nervous. Liglit. Weakly and cannot get around very well. Excited when spoken to. Does not go to school. Treated better than brothers and sisters. Father thin and tall, mother short and stout. Grandfather weighed $x 00$.

2. F. $18 \frac{1}{2}$ yrs. old. $4 \frac{1}{2}$ ft. tall. Weighs 105 . Dutch. Light. Phlegmatic. Good-natured. People said to her and brother on street. one night: "Say, but your mamma is looking for you" Parents small.

3. F. 22 yrs. old. 2 ft. 2 ins. tall. Looked about 4 years old. Light. Very ugly. Cannot talk. Brothers and sisters nice looking Mother large and father average size.

4. F. 6 yrs old. Fair. Height of three year-old brother. Delicate. 
Petted more than othet children. Does not go to school. Parents large.

5. F. 8 yrs old. Looks 3. Spiteful. Children of her age at school think her too sruall to play with them. Ancestors ordinary size.

6 . F. 20 yrs. old. $4 \mathrm{ft} .2$ ins. tall. Light. Had scarlet fever at 8 and has grown none siuce. Face looks old. Intelligent. Dresses as a child.

7. F. 7 yrs. 8 mos. old. $21 / 2 \mathrm{ft}$. tall. Light. Nervous. Size of child of 4. Seut to hospital when a year old, because her eyes "rolled back." Canuot fix her eyes on any special object. Has what appears to be small stumps of sixth fingers on hands just below thumbs. She is bright and can walk and talk as well as any one. Has not lived at home since a year old. Her mother is nervous and cannot bear her. A sister of normal size died at 4 . Parents average size.

8. F. 5 yrs. old. Could be put in sister's doll carriage when 3 . Was never able to walk, and died at 5. Could say but a few words. Parents large.

9. M. 15 yrs. old. Light. Bilious. Grown but 2 ins. in last two years. Was so small his mother kept him in dresses until he was 9 years old. Every one turns to look at him. Much petted at school. Mother's side of family small as far as can be traced.

10. M. Io yrs. old. Weighs 43 pounds. $3 \mathrm{ft}$. 10 ins. tall. Dark. Disagreeable. Has not grown more than ove-half inch in last two years. One day when a strong wind was blowing he did not reach school until late, because he had to wait until some one found him and carried him iu. Parents large.

1I. M. 16 yrs. old. $4 \mathrm{ft}$. tall. Light. Good disposition. Every one used to make fun of him for his smallness. He would go home and cry aud often not come out for two or three days. Used to eat all the time to make himself grow. Parents and grand parents average size.

12. M. 12 yrs. old, weight 65 . Very short. Was irritable, and petted at home. Children used to ask him when he was "going to grow," and tell him to "take that brick off his head." Such children should be shown more consideration. Not inherited.

13. M. 34 yrs. old $3 \mathrm{ft}$. tall. Shape and size of a 4 year-old. A brother who died at zo was about the same, excepting a man's liead. Parents ordinary size.

The small, for the same reason that large children associate with and are dressed like older children, prefer to be with younger children, and are usually dressed to appear younger. In more than one instance has it been mentioned that young women are dressed like young girls. While of the large more was expected and demanded, with the small the reverse is true. They are treated as children long after they are men and women in years. The treatment of the large, according to size rather than age, led to premature development. Similar treatment of the small leads to the opposite result-delayed development.

The healthier ones of this class show great activity, both of body and mind, but there is a very marked increase in the number of cases showing degeneration. A great many died early, others are "delicate," "could not speak," "were ugly, deformed, or vicious," and still others were "dull, mean, and spiteful." It is at once evident, on the basis of the cases 
reported, that the small, as a class, are much more strongly pathological than the large, the notice and treatment which they receive being far more likely to produce morbid tendencies.

\section{STroNG.}

I. M. Io years old. Dark. Irritable. Large boys held him in respect for his great strength. Small boys all cleim his friendship. Older sister was in subjection, while he was master of the household. Was often punished at school for " picking quarrels." Would suggest use of his strength at work. Paternal grandfather quite strong.

2. M. I2 yrs. old. Could put 25 pound dumb bells over head three times with either hand. Could lift I95 pounds to hips. Had to do heavy work at home. Had respect of other boys. Parents and grandparents strong on both sides.

3. F 13 yrs. old. Dark. Can move pieces of furniture which her mother and sister together cannot move. Is a favorite at school. Can be traced through four generations on father's side.

4. F. I8 years old. Fair. Nervous. Raised herself on nurse's lap at 2 weeks old. Walked at 7 mos. old, and ran at Io. Arms always very strong. Was the ruler of her set of girls at school. Lifted corner of piano up while her mother put the leg in. Had a severe attack of sciatica at 15 , and has not been strong since. Heroine of the school. Grandfather quite strong.

5. F. I4 yrs. old. Can tire out her father in a scuffle, and he is a large, strong man. Girls at school do not dare to have much fun at her expense.

6. F. 12 yrs. old. Sew her carry a young lady across the room. "Shows off" her strength, which has the effect of making her coarse and unrefined. Do not think the trait inherited.

The individuals of this group are frequently the leaders of the children with whom they associate. "Was respected," "All the smaller boys claim his protection," "Is not teased," "Favorite," "Petted and admired and had first choice." "Heroine of school," and "Girls did not dare have much fun at her expense," are some of the expressions which show the nature of the influence. Fighting, harshness, daring, coarseness and roughness seem to characterize, to a degree, this class. They are given more work than others and more is expected of them. They seem to receive more punishments than other children, and punishments do not seem to have the depressing effect that they might on some others. Their wrong doings seem to be the result of an extra sıpply of energy, and not to be premeditated.

\section{Bodiry Wrakness.}

I. M. I2 yrs. old. Pale and irritable. W:ak legs and had to wear them in iron braces. Had refect at birth. Walks with crutches. Often falls into fits of crying and passion, for which teacher scolds him. Pupils tease him. Petted at home. Not inherited.

2. F. 5 yrs. old. Spinal weakness. Been troubled so since birth. Has to wear plaster of Paris jacket all the time. If this be taken off she has to lie in just that position on the bed. Not inherited.

3. F. 7 yrs. old. Precocious. Healthy as a baby, but as she grew 
older, showed spinal weakness and is now bent almost double. Suffered a great deal but has never complained.

The marks of degeneracy to be observed in a milder form among the birth-marked and ugly, and more pronounced in the deformed, seem to be yet stronger in those having bodily weakness. They are both ugly and deformed in addition to their special defect. Theirs is a pitiable lot. Mental defect is, of course, common. Some are cruel. The infrequency of inheritance, as a cause, suggests the thought that the greater number of such cases are a result of the indiscretions and ignorance of parents-especially during the embryonic period. The weakness is so great in most cases as to prevent going to school, and away from home very often. They are a special care most often, and are kept out of sight occasionally. The temperamental conditions of such children is apparently very bad.

\section{DEFT.}

1. M. 20 yrs. old. Deft in use of tools, at wood work, and in repairing bits of machinery. At lo took a Waterbury watch apart and put together again. When any little article was broken be would say : "never mind, I will fix it."

2. M. Io//2 yrs. old. Generous and good-natured. Marte I 75 peach baskets in 9 hrs., which requires an exceedingly deft hand. Encouraged at home and praised by teacher, who receives many tokens of his regard. Pupils look up to him. Father and grandfather deft in the same way.

3. F. I4 yrs. old. Light. Phlegnatic. When 5 was ill with scarlet fever and lost use of lower limbs for a while. During this period she began to fashion doll's clothes and to sew. Learned to crochet and make doll's hats. Made fancy patterns and her own dresses at 13. Did not go to school until I4. Consulted in everything by schoolmates, who thought her wonderful. Always aided in decorating for school entertainments. Through mother and great grandmother.

4. F. 12 yrs. old. Light. Pleasant. Deft with fingers, and crocheted before 5 , tidies out of darning cotton. One for grandmother's rocking chair, and one for piano stool. Could play piano well at 6 . Made rapid progress under instruction. Neither parent so.

5. F. 8 yrs. old. Skilled in crocheting, was foud of it and could inake most difficult patterns. Would take her work to school, but teacluer had her stop it and take exercise as other children lirl. Not iuherited.

\section{AGILE.}

I. F. 5 $1 / 2$ yrs. old. Dark. Could dance all the popular dances at 2, and turn somersaults forwards and backwards. Could kick higher than her head. Once 3 ins. above, and people made up a purse and gave her. People often asked to take her to parties and dances to entertain. Much praised. Paternal grandmother agile.

2. M. I2 yrs. old. Runuer of school and won in all the races. Would get him to run at recesses just to see him. Made much of and looked up to. Does not seem to be itherited.

3. M. 16 yrs. old. Light. Run faster, jump farther, and play ball better than any of his schoolmates. Could turn hand-spring forward 
and backward. Pupils almost worshipped him. Now travels with a show as a contortionist and all-round athlete. Parents not noted for agility.

4. F. 14 yrs. old. Dark. Thought nothing of putting her hands on a fence and vaulting over, dancing clog dances, playing ball, turning somersaults, climbing trees, sliding down banisters, etc. Was thought wonderful at school, especially by girls. Do not think it hereditary.

The notice which children of these groups receive is very generally that of approval and appreciation, and therefore calculated to stimulate. This leads in some instances to "showing off." They are "favored," " petted," " worshipped," " appreciated," "looked up to," "shown more attention," "given more privileges," etc. The agile seem to have the better health, while both appear to be rather undersized. In some cases it seems that the deftness is an acquisition dependent upon some defect-the individual being left no other choice than to follow work which results in such skill. The first are more often generous, popular, and fond of play.

\section{Cr.jussy.}

r. M. Blonde. When suall was continually stubbing my toes and falling. Lell dowu stairs several times. Fell down once going into church. Once before the senior class. Was always laughed at, both at school and home. Grandfather clumsy.

2. F. I4 yrs. old. Light. Sure to fall every time she went out. Fell over the carriage stepping stone one day. Mother had some sunall ducks and chickens in the yard, aud every time $K$. went out she was sure to kill one by stepping on it. Neither parent so.

3. F. 8 yrs. old. Light. Nervous. Clumsy ever since a baby. If she has anything in her hands she is sure to drop it. Upset everything: she touched, and when she was walking looked as if she were sure to fall. Ridiculed at school. Not inherited.

4. F. 5 years old. Falls over things. Takcs an age for her to get out of people's ways. Mother calls her clumsy and gave her that name for a while. This made her almost cry. Do not know alsout inheritance.

But a few cases of this class are reported. It appears from these, however, that clumsiness is of two kinds as to origin. It may be due to excessive inhibition of the accessory movements and therefore be a form of nervousness. Also it may be due to a want of development of the mechanism that functions these accessory movements, which is clumsiness as ordinarily understood. These are subjected to much uncharitable attention.

\section{BEAUTY.}

I. F. 4 yrs. old. People stopped to admire. Artists wanted to paint her picture, and nejghbors borrowed her to show their company. Not inherited.

2. M. 3 yrs. old. People all want to kiss him when his grand 
mother takes him to church. People often call to see him. Allowed to do about as he pleases at home. Inherits from father.

3. M. 8 yrs. old. Between 2 and 6 , people always noticed and commented on his beauty. Would talk to him and take him ap. Teachers and older pupils flattered and petted him. Made him quite vain. Was also large. None other of family especially good looking.

4. F. I5 yrs. old. Fair. Made a great deal of at school and home. Said to her aunt one day: "I don't want to go out walking any more. People stare at me so." Inherited from father. Mother died when girl was 13 .

5. F. 9 mos. old. People all look at her. Mother is afraid for any one to touch her, can't find clothes good enough for her, and won't let her cry for a moment. Not inherited.

6. F. English. Every one noticed her. Mother told she ought not to allow her to go out on street alone, as she might be kidnapped. Did not know she was good looking. One of ejght children. Parents and grandparents good looking.

7. F. 7 yrs. old. Light. Bright. Conscious of her beauty, and often found admiring herself in the mirror. Favorite at school. Parents died when she was young.

8. F. 9 yrs. old. People on the street turned to look at her. When she started to scliool, pupils and teacher began to pet her and tell her she was pretty. She grew vain. This was discouraged at hoine and she is uot now so vain. Both parents good looking.

9. F. I5 yrs. old. Dark. Good disposition. Picture was painted and exhibited at the Art Club, where many stood to gaze at it. Teacher had her sit on front seat so she could see her. Imaginative. Not known to be inberited.

10. F. 3 yrs. old. Fair. Germav. Courageous and inquisitive. Beauty can be traced through three generations.

11. 5 yrs. old. Also vain. Once asked her teacher if she did not think her the prettiest child in her class. Said all her folks were handsome, but that she was the most so. Told me one day she was prettier than $F$. because her eyes were large and brown, while $F$.'s were small. Was told at home that she was not pretty, but admired at school.

12. F. 6 yrs. old. Blonde. Noticed on the street. Petted and has nicer clothes than the other children. Pettel at school. Self-conscious and haughty as a result.

13. F. 7 yrs. old. Received $\$ 100$ prize at Columbian Exposition. People told her she was pretty. Mother would tell her to look in mirror every time she put a clean dreas on her. Knew she was pretty and was conceited. Her mother and maternal grundmother good looking.

14. F. 4/2 yrs. old. Also very orderly and dignified. People all turn to look. Parents try to keep her ignorant of her beauty. Inherited.

15. F. 7 yrs. old. Every one thought her pretty. Allowed to do nearly everything she wanted to at school. Mother and grand. mother good looking. Also two sisters.

16. F. $71 / 2$ yrs. old. Much noticed. Treated much better than other children. Parents good looking.

17. F. 7 yrs. old. Has always been taken about a great deal. Has everything nice and new, while her little sigter wears any old thing and is left out. Entirely too much petted. Family are good looking.

18. M. 7 yrs. old. Light. Mild. When bis aunt took him out walking people turned to look at him. Mother dressed him well and gave him more attention than other children. Aunt beautiful. 
No other one of the classes studied receives an amount of attention so unusual. In no other class is the evil effect of unusual attention so apparent. In very few instances has it not been the most obvious cause' in producing vanity, and its related qualities, as selfishness, unkindness, haughtiness, pride. It is little wonder that beautiful children have these traits and that they like to show themselves, and to have an unusual share of attention as they grow older. It is exactly what they have been educated to expect. They have been "petted," "indulged," "flattered," " better dressed," " always taken out," "given prizes," "given preferences," until the wonderful thing would be that they should have a natural estimate of themselves and of their relations to others. The evil effects of their treatment is no doubt counteracted in some measure by better health than the average child possesses. Perhaps those who are guilty of thus doing such incalculable harm to helpless children, excuse themselves upon the ground that it is out of good will and admiration, but none the less it is a great wrong, and one which common sense would do much to correct.

\section{UGLY.}

I. F. I3yrs.old. Sallow. Bilious. Disagreeable. Sisters ashamed of her and do not care to be seen with her. Classmates shun her and call her "little Miss Ugly." Don't think she would be so disagreeable if treated nore kindly. Father homely.

2. F. 9 yrs. old. Light. Nervous. Ugliest person ever seen. Looks like a monkey. Peaked face, turned up nose, bulging eyes, and thick lips made to project by her teeth. Petted at home and teased at school. Backward. Mother the same when her age.

3. M. 21 yrs. old. Light. Mild. Small head, large nose, small mouth, chin sloping very rapidly to the neck, and a squeaky roice. Far below average. Tormented exceedingly. Parents small, but not ugly.

4. M. Polish-Danish. Dark. Some are afraid of him. Not known to be inherited. Parents in Europe.

5. M. 12 yrs. old. Looks like a monkey. Every one looks at him. Boys jeer at him and chase him. Parents very indulgent and kind, but seldom take him anywhere. Shunned at school by teacher and pupils. Is so conscious that he will not meet any one if he can help it. Parents and grandparents fine looking, but a great-grandfather uglier than he.

6 . F. 10 yrs. old. So ugly that every one turns to look at her. Dark and gloomy. Few children will play with her at school. Mother not quite so ugly.

7. F. 4 yrs.old. Light. Passionate. Small, flat nose. Ugly mouth, always open, showing an ugly set of decayed and broken teeth. Almond-shaped eyes. People rough and cruel to her. Mother homely, and grandfather especially so.

8. I. 9 yrs. old. Light and nervous. Horribly ugly. Looks like a monkey. Makes one shiver to look at her. Cross-eyed, near-sighted, pug-nosed, upper lip long, and projecting teeth; whipped one moment and petted the next. Father good-looking and mother ugly.

9. F. II yrs. old. Dark. Disagreeable. Fivery one noticed her. 
Children at school mistreated her and teacher punished her for almost nothing.

Io. M. 7 yrs. old. Dark. Obstinate and stubborn. Broad, fat face, low forehead, large, straight mouth and thin lips, with dark, watery eyes. Parents unkind to and dislike him for his ugliness. Either teased or aroided at school. Teacher punishes him for stubbornness and he cries because his feelings are hurt. Inherited.

11. M. Io yrs. 9 mos. old. Irish. Ugly character. Father divorced from mother for cruel treatment. Mother thinks her children faultless. Seems to be inherited.

That disorders of a fundamental kind are behind an ugly face more often than a comely one, is suggested by reference to the other bodily and mental conditions which are more or less characteristic of this class. There are records of divorces and disreputable parents, of obstinacy, stubbornness, backwardness, gloominess, mental defect, nervousness, etc. That these mental abnormalities might be largely the result of unkind and inconsiderate treatment, and that they might be lessened by right treatment, is probably true, but that there is a predisposing physical basis for them must be admitted. Mere ugliness of face does not imply degeneration, but that it is more often found among those who are degenerating, or who are already degenerates, seems a fair conclusion. The taunts, stares, and indignities in general which the ugly are subjected to, are extremely cruel in many cases. They are shunned, even by brothers and sisters, and left at home by parents occasionally. Indeed they seem, in some instances, to soon prefer the quiet of home life.

\section{DEFORMHD.}

I. M. 14 yrs. old. Dark. Pblegmatic. Born an apparently healthy child, but it was found at 2 that he could not walk. Remained so for two years, when he began to walk without touching heels to floor. Became somewhat stronger, but limbs remained stiff. Strength failed at 13 , and now he cannot walk at all. Josing strength in arms. Father humors him, and brothers and sisters have to obey him. Traced for three generations. Brother and sister afficted the same way. Sister committed suicide at 18 . Father has two sisters with same trouble.

2. M. I8 yrs. old. Born without right hand. Pupils used to ask him to do things which they knew he could not do. Had an uncle without left hand.

3. M. I3 yrs. old. Club-foot. Sensitive, and goes among older persons because the boys torment him. Has a brother of $I 1$ with similar deformity. No other such case ever known in the family.

4. M. I4 yrs. old. Dark. Good-natured. Had a hand like a turtle's claw, and was called "snapping turtle John" at school. Always carried hand in pocket. Not known to be inherited.

5. M. II yrs. old. Light. Hunchback, caused by an injury when

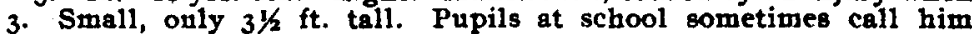
"old man" and "granddaddy," but he takes it good naturedly.

6. M. 9 yrs. old. Club-foot. Played with other children but the foot would soon get tired, and he would have to stop. Regarded with awe by other children. Not considered hereditary. 
7. M. 7 yrs. old. Short leg from birth. Thin, bright and active. Uses good language. Very mischievous and always teasing other children. Much spoiled ou account of his deformity.

8. F. Io yrs, old. Light. Nervous. One foot shorter than other. Mother always complaining about the trouble her sickness causes. Brothers and sisters impose on her. Allowed extra privileges at school.

9. F. Born with only one leg, and this remained about a foot and $a$ half in length, though the foot was normal size. Head, arms, and body grew all right. Was very strong in arms. Was in a perfect agony if she saw any one or anything suffering. She fully appreciated her disability.

10. F. I y yrs. old. Born with left hand off at elbow. Petted at home and much liked at school. Very generous, and choice about her food. Likes sweetmeats. Not inherited.

11. F. 7 yrs. old. Right ear is simply a roll of cartilage about one inch long and no opening. Bright. Has never gone to school on account of deafness and fear of being teased. Nothing like it in family.

The hard lot and degenerative tendencies of the ugly are seen in a much more pronounced form in these. It is strongly suggested that the deformity is but the sign of a rapidly degenerating stock, although this is not a necessary inference in each case. Some of those reported are of extra-uteral origin. They are very commonly afflicted with nervous disorders, are delicate and small, and have speech, mental and sense defects. They are sensitive, timid, despondent, and sometimes spiteful. They are frequently sympathetic and generous.

There are five that are the only children in families, and one is the youngest child. ('Duncan has observed that the first, and last born, are much more liable to be defective, both mentally and physically, than are others.)

Again, 37 of the 62 of this group are boys, or about threefifths, while two-thirds of the 1,045 cases are girls. Thus boys appear to be much more liable to deformity than do girls. It was at first supposed that perhaps this might be due to the easier observation of deformities in boys on account of their manner of dress, but this seems to have little basis in fact.

Warner found in his studies of Iondon School Children that $8.27 \%$ of the physical anomalies belonged to boys, while $6.78 \%$ belonged to girls. This is in harmony with the common observation that woman is the more conservative of the two sexes. This phase of heredity will be considered in relation to boys and girls, in another place. An observation of Newsholme ${ }^{2}$ is suggestive in this connection. He says. "The males outnumber females in still-births, probably owing to the greater difficulty in birth. Thiss in the ten years $1865-1875$, there

1 "Sterility in Women." Duncan. pp. 66 and 67.

¿Vital Statistics. p. 6r. Newsholme. 
were in France, r44; Italy, r40; Belgium, I35; Sweden, r33. and in Prussia 129, to every roo female still-births." It seems reasonable to suppose then, that not only deformities incident to difficulty in delivery, but those which may be due to intranterine disturbances are much more likely to occur with boys than girls.

It should be observed that 7 of these are of non-American parentage.

The record of their treatment is saddening, and leads one to think that deformity in others is a source of pleasure to many at all times, and perhaps to all at some times. They are " ridiculed," "stared at," " shunned," " regarded with awe," "left at home by parents," and very frequently do not go to school, and prefer to stay at home in order to escape the unkind notice which they receive elsewhere. Probably very few people appreciate in any right sense the sufferings of this class of unfortunates as a result of the cruel stares and remarks of others. It is not at all strange that they are lonely, strange, despondent, melancholy, and refuse to "go out."

Yet there is good reason to assume that, in cases which are not so much a result of bodily disorder of a too general and fundamental character defects have served as stimuli. Perhaps every person could name an example of such out of his personal acquaintances. Byron, Pope, Aristotle, and many others might be named as striking illustrations that all the world knows more or less about. Obversely, there are no doubt few who have not known some individuals so unconscious of pains or defects, so completely and overwhelmingly satisfied with the mere pleasure of existence, that life has had no serious meaning for them.

\section{Birthmarks.}

I. M. 13 yrs. old. Irish. One whole side of face, from foreliead to chin, a fiery red. People frequently stop him asd ask if he has burned his face. Not inherited.

2. M. 4 yrs. 9 mos. old. Light. When 9 mos. old his mother let him fall against a hot stove, burning left hand and left side of his face, so that he now has a very noticeable scar. The third and fourth fingers are much shorter and thicker than the others, and he carries them in such a position as to prevent them from being seen.

3. F. Ig yrs old. On left haud and arm a continuous red blotch, so conspicuous that she usually wears the hand gloved. Always caused comment among pupils.

4. F. 6 yrs. old. Light. A very decided red spot on her left hand She found that by rubbing it, it might be made to disappear for an instant, and will sit rubbing it by the hour. Neither parents nor grandparents have any such scar

5. F. 12 yrs old Dark. A sheet of fiery red skin covers one side of her face. She always thinks of it when in company, and says she does not like to go anywhere on account of it. Not inherited

6. F. 12 yrs. old. Dark. Nervous and sensitive. Browuisn red 
mark on right cheek which looks like a scar from a scald or burn, extends over whole cheek. Often spoken to about it and laughed at at school. Not inherited.

7. F. ro yrs, old. One side of face a bright red, and the other a perfect white. Attracts attention wherever she goes. Do not know about the heredity.

8. F. I4 yrs. old. Has a small triangular piece out of lobe of the right ear. Subject is a sore one to her. Brothers, boy-like, used to tease her by saying the angels-liked her so well that they held on to her fast enough to rip a piece out of her ear. Not inherited.

9. F. I 2 yrs. old. A large, red mark, on the cheek under the eye. Her family never mention it to her, as she is very sensitive about it. Some of her schoolmates who notice it for the first time, mention it to her, but never rillicule. She is also a whining child. Not inherited.

ro. $F$. I 4 yrs. old. Born with a small lump over right eye. This grew until now it is as large as a hen's egg. Until 12 could use the eye by lifting up the lump. Was a great favorite at home. At school, strange children used to stare at her a great deal, which pained her very much. Not inherited.

II. F. 14 yrs. old. Mark on back of neck. One of the brightest, finest girls in school. Girls used to make remarks which she overheard, and though she would not say anything about it, one could see was very much pained. Does not go out in cornpany on this account. Not inherited.

The signs of degeneration are not nearly so marked in this as in the two preceding groups, viz., deformed and ugly, but they are nevertheless not wanting. Speech defect is reported in four instances, while bad health, deformity, and ugliness, are noted in others. They are sensitive, whining, morbid, despondent. The behavior of others toward them is of the same character as that toward the two classes above named, and tends to produce similar results. That it should not do so in so pronounced degree may be owing to their better average health.

\section{Sense KeEnNess and Mentar, Precocity.}

1. F. I6 yrs. old. Keen sight. Ever since a little child able to see loug distances. Called needle eyes by friends. Father's home on a peninsula. Aunts could look across to opposite shore, a long distance, and distinguish persons. Inherited from father for four generations.

2. F. 3 yrs. old. Dark and nerrous. Keen sense of smell. Could tell kind of food cooking, flowers in next room, or if one bad been eating candy. People tested her wherever she went.

3. M. 4 yrs. old. Fair. Sense of smell keen. Can detect odors that others fail to notice. Could smell onions in the house where they had been cooked day before. All laugh at him at home. Mother's sense of smell good.

4. M. 4 yrs. old. Light. Plump and rosy. Very bright. Good memory. Knows a great deal. Can sing sweetly. Very inquisitive. Subject of his inquiries is often God. Affectionate. Pride of family.

5. M. 7 yrs. old. Nervous. Eng.-Scotch-Irish. Fair. Precocious and beautiful. Eas for music and sang from time he talked. Very neat and orderly. Somewhat stubborn and inclined to tease. Not selfish, but sober and thoughtful. Active but not boisterous, which may be due to the continuous companionship that has existed between him and his grandmother from his infancy. He is a little "old man." 
Mother is a careless, thoughtless woman, and has left care of hoy to her mother, who is educated and refined.

The amount and character of the attention which the children of this group receive, is no doubt responsible for much that is peculiar in them, but there is reason for assuming that this is by no means the important factor. While unusual development is reported in not a few cases along some lines, there is ground for the inference that more of the cases are abnormal, if not pathological, than otherwise. These children are often vain and self-important. Quiet surroundings, rather than such as stimulate, seem better for them.

\section{Sanse, Man'al and Spezch Dafiacr.}

I. F. I 3 yrs. old. Fair. Slow in reading and writing. Strong and healthy. Good disposition. Can do any kind of house work. Has been sent to school many times, but the teacher would always send her home with note saying she could not learn anything. Has a bright, kind face. Parents are intelligent.

2. $M$. Io yrs. old. Light. Poor hearing. Often fights with the boys because he thinks they are talking about him. School children plague and annoy him. Not inherited.

3. M. 30 yrs. old. Dark. Mentally dull. Can work the most difficult problems of mathematics and is well acquainted with sciences. On the other hand, does not know enough to put his hat on, comb his hair or even to eat. Has to have some one look after him all the time. Is the son of a professor. Not inherited.

4. F. I4 yrs. old. Speech defect. Delicate, as a child, and has never been able to speak more distinctly than a child of 2 . Is obstinate and will sit for a whole day wherever she may happen to be placed. Eats heartily, but meals have to be taken to her. Seldom speaks to any one. Will tear her clothes in strips and acts as if insane. Sent to school but learned nothing. Father sometimes whips her, which seems to be the cause of her stubborness. Family healthy.

5. M. Io yrs. old. American. Florid. Inclined to be phlegmatic. Poor hearing. When he came to school at 7 years of age, was next to impossible to understand him. Has had the school room drill in phonics and can make the vowel sonnds, having improved greatly. Can now usually pronounce a word by sounding it. Inclined to leave out unimportant words in speaking. Munbles some sort of jargon when not ready to answer a question. Reads badly. Has learned to watch people's lips and gets familiar commands and remarks in that way. Is popular among his playmates. Face babyish though bright. Have tried to have him place vocal organs so as to make sounds which he cannot hear well enough to understand. Father a butcher and boy probably eats much meat. Mother cannot hear well.

The peculiar defects in this group are very often significant of general decline. The individuals seem to prefer, in many cases, and are usually allowed, the seclusion of home life. Many are entirely dependent. All would be better off if provided with special instruction, and most are in imperative need of it. The public school as now conducted is hardly the place for such. 


\section{NERVOUS.}

I. F. 14 yrs. old. Dark. American. Also sensitive aud sympathetic. Least excitement causes great coufusion. Harsh words affect her deeply. In after life these traits will affect her in at least three ways. She is so nervous that she will never be strong and healthy, so sensitive that she will never have self-confidence sufficient to make her way, while the two combined will make her impulsive and lead her to do many rash things. 'Teacher does not seem to understand her. Kept from excitement and never found fault with at home. Would treat such persons with firm kindness and insist on having anything begun completed. Caused by physical condition of mother before birth of child.

2. F. 13 yrs. old. Light. American. Learned readily when she could apply herself. Slightest noise would cause her to jump, and often to scream. A vivid imagination and a disposition to overstatement. Once in telling the teacher about a quarrel between two boys she said they tried to kill each other with knives. Did not seem to mean to misrepresent, but to believe what she said. Severely punished at home, where her surroundings were bad. Parents drunkards. Mother especially violent.

3. M. ro yrs. old. Light. American. Cannot sit still at school. Especially noticeable in arithmetic. If he fails in his problem the first time he cannot try it a second. Seems to lose all self control at times. Although he can give recitations when alone, it is well nigh impossible for him to do so before the school. Has been severely punished in school for not keeping still. Should be kept from excitement.

These are characterized in the main by delicate and unstable constitutions. They are below, rather than above, the average in size, inclining to be slim; are timid, sensitive, changeable, and sometimes said to be untruthful. They are disposed to be irritable and annoying, and show a sort of inquisitiveness, bordering upon meddlesomeness. The apparent disregard of truth, and the manifestation of a meddlesome spirit, is perhaps due to the want of self-control. The actions of such persons lead others to make sport at their expense, so that association with others, as in the ordinary school life, church and Sunday School, and participation in public exercise of any sort, has the effect of stimulating the trouble. Much of the pleasure which some seem to derive from their behavior toward such individuals is downright cruelty -is entirely too serious for comedy.

\section{Creman.}

1. M. 6 yrs. old. When quite small, if his apron became soiled he cried until it was changed. Hands and face gave similar trouble. As he grew older the trait was intensified in a spirit of painful neatness. By actual observation he was once known to stand 20 minutes before the mirror brashing his hair. If any one placed a hand on his head, he at once went to the mirror and began to brush his hair. Delicate health and was tanght at home. Through father and father's mother.

2. F. 18 yrs. old. Nervous. When small would cry, if clothing was soiled, until it was changed. Favorite play was "wash day" or "cleaning house." Never could go past a pump or wash basiu without 
washing my hands. Dirt makes me nervous. Know it is silly, but "cleanliness is next to godliness." Mother a dirt fiend.

3. M. 6 yrs. old. Orderly and quite nervons. If his hands were dirty would cry until they were washed. Clothing must be absolutely clean. His mother could not wesr clothing the least bit soiled, for he would scream until she changed it. Did not go to school. Mother much less so than he.

4. F. 5 yrs. old. Light. Could not endure sight of dirt. Wanted a clean dress on if there was least speck on her clothing. Would not play and get dirty as other children. Sits quietly and plays with her dolls. When her little sister came in dirty from making mud pies, she would drag her to the wash basin and scrub her face with soap and towel until it fairly shone, then comb her hair and get a clean apron for her. Parents and grand parents exceedingly neat.

5. F. $21 / 2$ yrs. old. Can't pass basin of water without washing hands and fare. Gets a cloth, soap, and water, and washes furniture. Will not use a napkin the least bit soiled, and spoons have to be washed about every time she puts them in her mouth. Parents nornal.

\section{Dansty.}

I. F. 4 yrs. old. Everything must be just so. At meals her mother has to get just what she wants. Once saw her refuse a cup of cocoa. When she saw others had it she fussed until she had some. Has whatever she wants. Neither parent so.

2. M. 9 yrs. old. Light. Nervous. Won't eat regetables or meat unless made to. Won't eat any kind of pie but pumpkin or any kind of cake but chocolate, and says he can't get enough of these. likes fruit, and wishes we could get nothing but fruit to eat. Sometimes will eat only bread and sugar. Is often scolded or punished for his daintiness and cries, then gets what he wants. Is pale and thin. No other of family so.

3. F. 17 yrs.old. Dark. Nervous. Used to be so particular about eating that would not go away from home for meals. Would eat only those things that were cooked just so. If they did not look as usual would not touch them. Always had to have my milk strained, so there could not possibly be a speck in it. Family never bothered much with me. If they had prepared what I wanted, I ate with them, if not, I did not do so. Think treatment right. Neither parent so.

4. F. 5 yrs. old. Irish. Delicate and sensitive. Very neat and orderly, especially about dress and work. Does not join readily in games, but stands aloof in a sort of critical attitude. Is very clean. Slow and has good memory. One of a very large, poor family, and has had to take care of the baby.

The associated peculiarities most often met with in the clean are orderliness, obedience, truthfulness, slowness, nervousness, fussiness, daintiness, and a critical spirit. They are not unfrequently delicate children, and are often beautiful. Also, there are several who are said to be quiet and dignified. They are very generally encouraged in the trait, but are restrained in extreme manifestations of it, while they are laughed at and made much sport of by some. In more than one case there is evidence that the peculiarity has become morbid, as when a child washes his hands every few minutes, or refuses to join in any games for fear of soling his shoes, hands, or clothing. 
Indeed the suggestion comes to one in looking over the records, that there is a pathological basis for many of the cases.

The dainty agree in the main with the clean as to temperament and health, though they are more often said to be delicate, feeble, and unhealthy. They are fussy, particular, spoiled, fastidious, nervous, complaining, and are pretty generally indulged in their moods and whims.

\section{DIRTY.}

I. M. 5 yrs. old. Never seems so happy as when in dirt. Will lie down and roll in it. Eat dirty grass, pretending to be a horse. Walks in muddy road with shoes on. Seems astonished on being told he is dirty. Would occupy him with clean plays and get him some clean, white sand. Do not know that it is hereditary.

2. M. 6 yrs. old. Dark. Happy when dirty. Sit down in dirt and cover himself with it completely. Cry if water is brought near him. Teacher washed his hands one day. He cried, and at recess went out in the street and smeared himself with dirt. Clothing always dirty, and hair never combed. Mother not a very clean woman.

3. M. 6 years old. Also disobedient and untruthfal. Never clean. Never told truth or obeyed. Parents or teachers could do nothing with him, though he had been punished in every conceivable way. Sent to Reform School.

4. M. 5 yrs. old. Always objects to being " cleaned up." When he fnishes making mud pies, wipes his hands on clothing. Once after being dressed, went out where the donkey was kept and smeared himself with filth, and came back in great delight. Should be whipped. Inherited from mother.

5. M. 2 yrs. and 7 mos. old. Never seems contented unless clothing and face are thick with dirt. As soon as "dressed up" will go out and jump head first into a dirt heap. Will cry and scream when the dirt is washed off. Is quiet. Mother dresses him and tells him how much better he looks than dirty boys. Not inherited.

Some children seem to have a love for dirt and filth in no way developed by surroundings. As for instance when a little child, whose parents and associates are noted for cleanliness, jumps into a dirt heap or a mud puddle, the moment he has had a bath, and a clean dress put on. Or, as when another, with similar training, blackens his face with coal dust, and seems satisfied. Perhaps other instincts of a more primitive form of life refuse to be overcome. Certainly there are many evidences of health and vitality in them, although they are disorderly and disobedient. Eleven of them are non-American.

\section{ORDERLY.}

I. F. I9 yrs. old. Fair. Had a great craze for order when a child. After playing, always put my playthings in order as before. If playing with neighbor girls, always went around and gathered up things before a new game, or when through. If we had company, and anything was disarranged, it worried me dreadfully and I could not rest until it was properly placed again.

2. F. 5 yrs. old. Dark. Worried if anything is out of place. As soon as she gets up in the morning she visits all the rooms to see if 
anything is out of order. If she finds anything she cannot rearrange, she wants her mother to come at once and attend to it. While visiting there, if I left my bureau disordered, I always found it had been straightened up by $A$. on my return. At night her toys are put carefully away and her dolls tucked away in their cribs. She says nothing when on her ordering expeditions, but hums the same little tune all the time. Her mother orderly.

3. M. 6 yrs. old. Light. Nervous. Every toy, book, etc., in his play-room in its proper place. One would suppose he never used them. Would not allow his brother to use any of his playthings unless he promised beforehand to return it to its proper place. Not hereditary.

4. F. 6 yrs. old. American. Pretty and graceful. Earnest and thoughtful. Quite bright in her studies. Nervous, and a slight stammering in speech. Is conscientions, and desires her work to be inspected in order that she may know if it is right. Makes rapid progress in her work.

\section{Obepight.}

I. M. Io yrs. old. Light. Attractive. Not strong. Has eye trouble and wears glasses. Dreads to think he may do wrong, and never does what he is told not to do. Once cutting pictures from paper on Sunday, when he remembered it was Sunday, it required the combined efforts of his mother and grandmother to have him continue. Truthiul. Good parentage.

2. F. 7 yrs. ofd. Light. Nervous. German. If her mother tells her the weather is unfit for her to play out at school, no amount of coasing can induce her to go out. Never hesitated in her obedience, eren though she disliked it so much that she cried. Great care should be taken that only just commands be given such a child. From both parents.

3. F. 3 yrs. old. Light. Once had a little friend visiting her who wanted everything she saw. F.'s mother told her to let her have them, which she did willingly. Is orderly, and always puts away her playthings as soon as through with them. Mother orderly.

4. F. 3 yrs. old. Most obedient child ever saw. Every one notices it in her. Once, when the grass was wet between our houses, her mother told her to go around by the board walk. Ever after that she would come round that way. Do not know about heredity.

The orderly and obedient might both be described almost equally well by either term. The first are clean, slow, patient, punctual, sometimes nervous, and truthful. The second seem to be, in addition, timid. Both are encouraged by parents and teachers and seem to be favorites generally. The orderly are inclined to give annoyance by their exacting methods. It seems to be true that obedience very often springs from timidity and weakness.

\section{Disobedient.}

I. M. Io yrs. old. When told to do a thing, will do the exact opposite. If told not to do it, will usually do it. If his mother tells him not to go skating, he will surely go.

2. M. 6 yrs. old. Also dirty and a liar. Teacher can do nothing with him, and parents but little, although they have puuished him in every conceivable way. Was finally sent to Reform School.

3. F. 7 yrs old. Beautiful aud praised a great deal on this account, 
which makes her disobedient. Will do nothing she is told to do. Never corrected. Mother the same make up.

4. F. $2 \frac{1}{2}$ yrs. old. Also dishonest. Broke a doll one day, and mother asked her who did it. "Why, John did it," she said. Would always do opposite of what she was told, if possible. Was told one day not to follow her grandmother, not to leave the door. In a few moments she was a distance up the street.

\section{DISORDERIY.}

I. M. 21 yrs. old. American. Dark. Sanguine. Always tearing his books or breaking something about him. Began book-keeping, but blotted his paper 80 badly that he had to quit. In returning chairs from hall to church he broke and scarred a number. Worked in a quarry, but his carelessness soon resulted in his discharge. Likewise in a rubber factory. He is of more than usual ability, and from a well-behaved and gentlemanly boy, has degenerated into a coarse, profane tongh. Was punished and scolded at home. Made to do work over at school. Mother somewhat so.

2. M. Io yrs. old. Dark. Had bad temper. Had no idea of order. When playing with blocks, could never get them in order nnless I watched some one else. Playthings and books always left where last used. Could never find anything when wanted. Frequently punished and corrected for it, bat did no good. Lasted until was about I4. Not inherited.

3. F. I7 yrs. old. Fair. Sanguine. When a growing child was very disorderly. Clothing always torn, ripped, or buttonless. Was constantly admonished to do better, but only slowly overcame the trait in a partial degree. Was kept in at school and made to put desk in order before leaving.

Disorder and disobedience are closely related. There seems to be more than usual energy behind both, especially the disobedient, who are occasionally mentioned as beautiful. They receive various kinds of punishment, as scolding, whipping, expulsion from schools, being sent to reform schools, etc. Very often they are dirty, untruthful, destructive, boisterous, of violent tempers, and disagreeable generally. Their treatment, as a rule, appears not only not to improve them, but to aggravate.

\section{TE,ASTNG.}

I. M. I2 yrs, old. Dark. Phlegmatic. Continually teasing younger children. Delighted when he could get dead snakes or live wasps with which to chase children. Had numerous devices for this purpose. Has been punished in various ways. Do not know about inheritance.

2. M. 4 yrs. old. Took the lemon squeezer out and put a kitten in it. When kitten mewed he laughed. Was left at home one day with his grandmother, who could not walk. He is not allowed to visit the sugar box, so he said; "Grandma, I am going to get some sugar, I am. Look, grandma, I am going. Here I go ! I've got some, two handsful !", Teased his 14 mos. old sister by taking her playthings. Will take things from other children and when they cry, he laughs. Has had many kinds of punishment.

3. M. I4 yrs. old. Never more delighted than when teasing some one. If could not find a person to tease would tease dogs, cats, or any 
animal. Did not do 80 because others disliked it, but because it came natural for him.

4. M. 12 yrs old. Teases every one and everything with which he comes in contuct. Cannot pass a dog or cat on the street without throwing or kicking at them. Think no notice should be given him when he does these things.

\section{Buoyant.}

I. F. $4 \%$ yrs. old. Light. Generous. If things do not please her she does not show it. If her playmates are not nice she tries to make them so by her example. If she displeases others accidentally she tries to turn it off. Has always been loved by all on account of her pleasing ways. Has always been discriminated against at home because she was so easily satisfied. Paternal ancestors so, but maternal irritable.

2. F. Io yrs. old. Always happy, never sad. Never knew her to be disappointed or unhappy. If she had planned to go somewhere and it rained, she did not care. She could do something else. If she broke her doll she could have another. Not inherited.

3. M. 7 yrs. old. Has red hair, which is his greatest delight. Good-natured, always happy. Never see a scowl on his face. Almost overjoyed when allowed to drive a horse, and will talk of it for weeks. Other children are always glad to play with him because he is so generous in sharing his playthings. Always running and jumping. Can't keep still. Always first on playgronud. Every one else may be gloomy, but he is smiling and happy. Not inherited.

4. F. 6 yrs. old. American. Fair. Small and rather delicate. Cheerfil and makes others so. Sometime inclined to tease. Inclined to be careless with her work and slow to take up anything new. Sociable and fond of companionship. Teacher never passes her desle but E. pulls her dress or touches her hand to get her attention, when she tells some little joke and nods her head in a very wise little way.

Buoyancy and teasing are alike in that both seem to originate in an abundance of vitality. Children of the former class have more of the characteristics of generosity and sympathy, while those of the latter are often cruel or nearly so, although very generally liked.

\section{BUFFOONS.}

I. M. 8 yrs. old. Dark. Mischievous and dirty. Does all sorts of thiugs to create merriment. Nothing pleases him better than to be laughed at. Children at school encourage him. Seems to be ruining him. From father.

2. F. I 4 yrs. old. Dark. Did all sorts of things to make us laugh. Was the clown at school. Rolled her eyeballs so as to show only the whites, stuck pins in her fingers, arranged her hair in some curious fashiou, looked cross-eyed, stretched her mouth in funny shapes, moved her ears, and said all kinds of amusing things. Much admired at school. Not inherited.

3. M. I3 yrs. old. Always doing something in school to cause the children to laugh. Tore the window sill with his teeth and hurt himself in such an attempt. If kept in to write words and some of them happened to be long, he would write some short word, as cat, to see the teacher laugh, although he were kept twice as long:

4. M. 6 yrs. old. Light. Cheerful. Will put things on his head or ears and walk about in some ridiculous fashion simply to see 
people laugh. School chiidren laugh at him and this encourages him. Is usually not noticed at home. Mother lively.

The buffoons are likewise characterized by an exuberance of spirits. They are healthy, dirty, generous in a way, and easygoing. The attention which they win from others is generally that of approval, and appears to satisfy a desire for applause or commendation. The grimaces and unnatural gestures perhaps satisfy an interest in the morbid which is akin to that shown in the deformed and ugly.

\section{Cruer.}

1. M. 16 yrs. old. 5 ft. 4 ins. tall. Irish-Swede. Stiff brown bair growing down over forehead, which is narrow and rapidly retreating. Small face, always wearing a dogged, sullen look. When quite young would smash dishes or anything about him, if angry. Once when left at home tied a stone about neck of mother's cat and threw it in the river. About 8 he took mother's molasses jug and poured contents all over carpet of sitting room. Nothing could be done with him at school. Loaded a stick with powder and put it in the schoolroom stove unobserved. Blew out sides of the stove. Was expelled from school. Later tried to drown younger brother. Now at Reform School. Mother used most brutal punishment. Once saw her spank her Io mos. old baby because it would not sit in its chair while she did her work. Father a hard-working, industrious mechanic.

2. Ms. 8 and 9 years old. Dark. American. Strong and bealthy, but make little or no progress in books. Heard their father say that two pups, about one week old, needed to be killed. When he was away they took them to a block and with an axe cut off the head of one, cut another open lengthwise, and a third crosswise, through the stomach. Are allowed to visit the slaughter houses. Not corrected often, but severely, as father does it when drinking. The trait can be traced two generations through him.

3. $M$. To yrs. old. Continually torturing birds by picking out their eyes. His cat had four kittens which his mother wished to do away with. He partially drowned them and then put them into a hole and chopped them into small pieces with a spade. Not inherited.

4. M. 9 yrs. old. Bilious. Mopish, sly, and underhanded. When he was about 5, saw him stick a pin in a fly and watched its agonies as it walked away. Has cut off cats' tails inch by inch, cut off the toes of chickens, put out the eyes of birds, cut off the legs of frogs and broken bills of chickens. Cruel to younger children at school, and was expelled. Was pleaded with and whipped, but did no good. Finally sent to Reform School. Father was a butcher, but not cruel. Nothing else like it in family.

5. F. 6 yrs. old. Picked up a little chicken and wrung off its head, then broke its legs. Delights to be "mother," when playing with children, so she can beat them. Reprimanded at home for it. Father a drunkard.

6. F. 6 yrs. old. Swede-Irish. Delights to see cruelty done. Once got out among some small chickens and was making short work of thein; when stopped, she was very angry and wanted to go back and kill the remainder of the "little hirds." Punishes dogs and cats iu any way she can. Father has been in a state's prison and lunatic asylum. Mother a rough character and nuch disliked by neighbors.

Cruelty appears to originate in the exercise of power over 
weaker living things. More is shown toward children than grown persons, more to small and young animals, aud perhaps relatively most to insects. Teasing is an allied trait. The presence of physical and mental defects might suggest a savage sort of revenge against all living things as the cause in some instances. Some of the cases are clearly the result of seeing the slaughter of animals. Perhaps some are the direct result of punishment, for there is a record of physical punishment in most cases, and in not a few of a brutal sort.

It is well to note that of the 22 cases, 7 are of foreign parentage, four of these being children by intermariage between different nationalities. One a French-English, one French-Indian, and two Swede-Irish. The presence of such pronounced cruelty in very young children, as is mentioned in some of the reports. would lead one to infer that it is the result of remote ancestral influence. Many, if not all of the children described, are unfit for association with others.

\section{SELFISH.}

I. M. II yrs. old. Light. Would never divide with his playmates or take his turn at being "it" in "hide-and-go-seek," but always ready for gain. Very much disliked on this account by other boys. Seems to be inherited from parents and grandfather.

2. F. 93/2 yrs. old. Nervous. Her mother told her one day, when she had some candy, to give her friends a part. She would not, and said they could get some from somebody else. She is a great talker, very inquisitive, and much spoiled.

3. F. 13 yrs. old. Light. Most selfish and gluttonous child ever seen. At table she always insists on having just what she wants, and before any one else. Several times when she had candy given her, she ran uy stairs and hid it where none but herself could find it. Pareuts never correct her. Not inherited.

4. F. To yrs. old. Fair. Extremely disagreeable. Seems to think of no one but herself. Always wants the best and largest share of goodies. Would cheat in playing with other children, rather than let another win. Never gave her playmates anything. Would do nothing she thought might please any one else. Always thought people should do whatever she asked them, and at ouce. Did not make many friends. Inherited from father.

5. F. 3 yrs. old. Will not let other children have her playthings or taste ber cakes and candies. Whenever her parents go out she must go also, no matter what is said. Everything she does shows selfishness. Parents never think of correcting her. Is not inherited.

The selfish are often mentioned among the cruel. They are sometimes gluttonous, loquacious, untruthful, spoiled or indulged. They often cheat to satisfy selfish desires. They do not join so actively in the plays of others, nor are they very much liked by other children. Selishness is one of the most striking traits of the only children in families. While it is no doubt stimulated by surroundings, in many cases, there is abundant evidence that health has quite as much to do with it. 


\section{GENEROUS.}

I. M. I5 yrs. old. Has many bad traits. Had \$ro with which to buy himself toys at Christmas. As he started into the store he met two ragged boys and gave them his money, going home without the toys. Favorite with other boys. Parents are generous.

2. M. 53/3 yrs. old. Saw a little girl crying for money to buy a doll with. Told her to stop, went in the house and got some money from his bank and gave her. Gave his mother's wrap to a poor lady. Imposed on on account of his generosity. Liked by every one. Called "Genny George." Can be traced three generations back.

3. F. 5 yrs. old Light. Active. So generous that she often tries my temper. Would insist on giving me things whether I wanted them or not. Never dare to let her wear anything valuable away from home, for she one day gave away her gold chain and diamond locket. Punished for her extreme manifestations of it. Father generous.

4. F. II yrs. old. Dark. When playing, is the first to give up her toys to those who want them. Farned $\$ 5$ one summer, and gave it to her mother to buy something for her, her father and brother, but said nothing about herself. Has more consideration than other children. Parents generous.

5. F. I5 yrs. old. American. Light and good looking. Good health and inclined to be fleshy. Always laughing and merry. Gives one a restful feeling to be in her presence. Willing to work, and assumes household cares in mother's absence, although she has two older sisters, who impose on her because of her good nature. Will lend any of her possessions. Somewhat careless, and a good humored tease. Did not worry much at being reproved. From mother.

\section{SYMPATHY.}

I. F. 17 yrs. old. One day brought a snake into the house to warm. Her brother was going to kill it, but she cried so hard that he did not do it. Always picking up bugs and such things, to keep them from being hurt. From father.

2. F. 9 yrs. old. Light. Nervous. Sensitive. Her sympathy is almost physical. If you say you have a headache, she immediately has one also. If you are sad or merry, she is the same. If she sees tears, she will cry. She easily detects illness in your face, and straightway is ill herself. Illness of others kept from her as much as possible at home. Taken advantage of at school. Do not know about inheritance.

3. F. Ig yrs. old. Could not bear to see animals suffer. Nearly broke my heart. Easier to see persons suffer, for they can tell of their troubles. Once saw a blind organ grinder who stood on the street corner from day to day, holding a little dog in his arms in a cramped position. Watched it for a while and burst into tears, never thinking of the man's infirmity or affiction. Mother so.

4. F. Io yrs. old. Light. Could not bear to see any one suffer or scolded. Would cry harder than those she saw punished. Once when her sister was slightly reprimanded at school, she cried until almost hysterical. Was laughed at and called "cry baby." From mother and her father.

5. M. I 7 y rs. old. Strong sympathy for animals. If I saw anything suffering, I seemed to experience the same suffering. Once father sold a cow to butcher. Cried so hard, had to be told she would come back.

Generosity and sympathy are nearly always found in the 
same individual. The first named appears to be the active side of the latter. It is faintly suggested that delicate and impaired constitutions are especially predisposed to be generous and sympathetic. Both classes are very general favorites, and their company is much sought after by other children, who easily and frequently impose on them. These feelings are quite as often manifested toward animals as toward human beings. It is very strongly suggested by some of the cases that sympathy is developed in not a few persons by some painful defect.

IMAGINATION.

1. M. 8 yrs, old. Ambitious. Will talk for hours about his farm out west. Every cow, horse, or pig he sees is compared with those on his farm. Would say: "I would not have such horses on my farm in Minneshota." Would tell how his agent, "John Bat," had shipped a car load of animals east, and he was expecting them every day. If asked why they had not arrived, would say "John" had come east and sold them. Wrote many letters to him concerning the care of the farm. One day he called to a stranger driving by: "Stop a minute, John!" When told not to do so, he said: "I know who that is ; it is my man John Bat." Not inherited.

2. M. 7 yrs. old. Dark. Happy. Said one day: "My papa is making cider and lets me drink it when first made, before it gets sour." His father was at the time ill in bed and never had made any cider. He said also another time: "Once when I was a baby I walked down to grandma's all by myself, and I could talk to her, too, and nobody teached me how." His grandmother lives in a town 5 miles away. Parents try to prevent his saying such things. Not inherited.

3. M. 20 yrs. old. When a little boy used to take horse-chestnuts, and calling them cows and chickens, would play with them for hours. Had an imaginary companion with me all the time. Before doing anything always asked this companion and gave answer myself. Talked aloud all the time. Parents unimaginative.

4. F. 2 yrs. old. Playing alone said: "You curl my bair, I'll curl yours." Then in a few minutes: "I curled your hair nice, but you did n't curl mine nice." Asks questions, and answers them in a changed voice. Playmates like her. Not inherited.

Imaginativeness characterizes many of the "only child" group and others who, for any reason, have not had companions of their own age. Such children resort to imaginary companionship. Burnt matches, horse chestnuts, dolls, or changed tone of voice serve to supply the companions. Not a few seem to indulge the power out of a desire for an enlarged personality, and become deceivers, if not liars.

\section{LYING.}

I. M. 6 yrs. old. Thinks a great deal of animals and guns. His father bought him a toy gun when he was about 4 . He went out to a creek pear the house, and when he came in, told his mother he had killed a rabbit out in the creek. Upon being told he must not tell such dreadful things, he replied: "Well, I saw something in the creek that looked like rabbits. I think they were rocks." Inherited from father. 
2. F. 7 yrs. old. Seemed a second nature. Lied when the truth would have answered better. Seems to prefer the lie. Was punished both at home and in school, and finally broken of the habit.

3. F. 7 yrs. old. Light. Everything she tells is a lie. Nobody believes anything she tells. If she hears any one tell anything, she tells something like it. Punished, but does not seem to do any good. Neither parent so.

4. M. Io yrs. old. American. Light. Tells his stories as if they were facts. Tender-hearted and conscience stricken when talked to about it. Have known him to take money several times, and once to take ro cents from his teacher, who suspected him and induced him to confess. Teacher has stopped him through fear of punishment, but he still lies to the boys away from school. Traced to parents.

5. F. 7 yts. old. Think it due to ignorance. Told the girls there was a snake down in the wheat field and that it ate all the wheat off. When she talks so at school the girls say: "Now E. come off. Don't tell us so many of those fairy tales. We have heard enough of them." Not inherited.

Lying seems to be nearly related to imaginativeness. Also it no doubt comes in some instances from a lack of self-command and self-assertion, while in perhaps the greater number of cases it is a result of imitation and a sort of personal interest. Its connection with, and dependence upon, the imagination in early life is quite evident. It seems to be a sort of exercise for the rapidly enlarging personality. Disorder, disobedience, bad temper, stealing, and bad health are other associated traits.

\section{ILL-TEMPERED.}

1. F. to yrs. old. Fair. Been so from a baby. Would scresm until noticed and taken up. When crossed she would throw herself on the floor and scream and kick for minutes at a time. Whipped frequently. Finally found that the best thing to do was to leave her alone in these spells until she gets over then alone. Much improved.

2. F. 10 $1 / 2$ yrs. old. Screams and fights. Scarcely a day without some show of it. Father teased her to have her show her "spunk." Boys teased her at school. Father and mother are quick, but never lose control.

3. M. I6 yrs. old. Ever since babyhood has had fits of gloom and ill-ternper, usually occurring about time of each full moon. Violent at such times. When quite young would beat his head on the floor in anger, and even now he seenis to lose entire control of himself, venting his anger on friend and foe alike. His mother says that as be grows older these spontaneous outbreaks are less frequent and violent. At other times lie is well disposed. Last August, at usual time, be was sullen and troublesome, any communication with others invariably ending in a quarrel. I asked him what the trouble was. He said he was angry with every one. When these attacks make their appearance he is left alone. Do not consider it hereditary.

4. F, 5 yrs. old. American. Pretty. Fair. Delicate and has taken a good deal of medicine. Once, when calling with mother, threw a glass tumbler through a window in a fit of passion. When sick would dash away medicine in a fury. Once, when visiting, said in emphatic tone there was nothing on table she wanted. Tyrant of home and indulged. Mother often says: "Why, L-, mamma is so sorry. Can't she do something for you?" etc., aurl gets in return, 
"Shut your mouth." Two brothers like her. Mother fussy and over-particular. When the girl entered schnol she proved to be bright and, contrary to expectation, showed a better disposition.

Peevishness, untruthfulness, discontent, nervousness, delicate health, so common in this group, suggest a sort of constitutional instability, a want of proper balance and self-control, as the basis of bad tempers. It is not necessary to infer the absence of energy and vitality, but it seems right to suppose a bad combination. The ordinary school and social life of children appears to stimulate the trait, and it is strongly suggested that a quiet, ever,, sympathetic, though firm and uniform mode of treatment, is best.

\section{SILENT.}

I. F. I3 yrs. old. Sallow. Bilious. Never spoke unless questioned. Would sit for hours thus. Would play with other children and let them do all the talking. Allowed to remain silent at home and not troubled at play to any great extent. Such children should be questioned more, given more self-confidence, as it is often these who have really interesting thoughts.

2. F. Io yrs. old. Light. Never played very much and usually preferred to be with older persons. When they talked she would keep very quiet and listen. Mother often urged her to go out and play with other children. If she had been allowed to go more with other children when younger, think she would not be so quiet. Inherited to a degree.

3. F. 7 yrs. old. Bashful and dignified. Seldom talks, especially when among strangers.

4. M. 9 yrs. old. Loves to sit by himself and talk to no one. Speaks only when spoken to. When his brother, who is the very opposite, goes out to play, G. remains in the house. Never soils his clothing. Has a sister about 4 years old who seems to have rheumatism in one of her feet and cannot walk.

5. F. 3 yrs. old. When we played together I did all the talking. Sometimes she would leave her expensive playthings and play with burnt matches for hours. Sometimes sit down in a cosy corner and remain quiet for hours. What she did say was unusual. Seemed to live within herself. As she grows older, talks more and seems to regret her quiet way. Always allowed to talk when she chose. A general favorite. Father a quiet man.

\section{Dignifred.}

I. F. 7 yrs. old. Iooks like a little woman as she walks along the street. Does not seem to play with other children. Enjoys company of older children.

2. F. 5 yrs. old. Fair. Phlegmatic. Does not care to play with other children, does not care for their games, and will not romp. Will play in a dignifed way with dolls and toys. Will come into the parlor and shake hands with her mother's callers and talk to them in a womanly way. No one thinks of treating her as other children. Parents pet her and think trait an excellent one. Such dignity is unnatural, and she should be taught to romp and play as other children do. Not inherited.

3. M. I4 yrs. old. Light. Phlegmatic. Never mingles with school children. Sat in seat and read during recesses. Conversation was that 
of a man of 25. Preferred company of older people. Teacher one day asked him if he would take drawing. He replied: "I have no talent in that direction and prefer devoting myself to reading." Carried himself erect on the street, and always lifted his hat deferentially to elders. Carried a cane everywhere but to school. Shoes always polished and clean. When a book of children's stories was given him he said: "Do they think I am a boy? Just as if I wanted to read such nonsense. I would much rather have had Stanley's in Darkest Africa?" Father died when he was four, and mother always called him her "little man." Was the only son and always accompanied his mother and sisters when they went out. Children look up to him at school. Strange to say, is not conceited and is obedient.

The silent and dignified are allied groups. The terms might be interchanged and be equally expressive. The silent are usually considered as dignified, and the dignified are usually silent. They are also equally likely to be clean, neat, crderly, obedient, particular, timid. Indeed it seems that timidity is very frequently assumed to be dignity. The general condition is not far from pathological, and it appears that both traits are very likely to have such an origin. The dignified, especially, are subjected to a good deal of teasing, but receive a good deal of petting and encouragement at home. Both kinds prefer the company of older persons, and thus, like the large, are sure to grow old in ways prematurely. It is unfortunate that this trait should receive the encouragement of older persons. They will not engage in lively games, involving running, scrambling, or loud talking.

\section{Frank.}

I. F. I7 yrs. old. Dark. Cannot keep a secret. If the girls asked me to keep a secret, I would say: "Yes, but I must tell mamma." I would tell her and everybody else's mamma before I knew it. Hurts me to keep a secret yet. Seems like a burden on me and I don't feel relieved until I have told some one. If it is good I want some one to share it. If bad I want some one to console with. Am never told anything at home except what all should know, which is perhaps right, although it sometimes hurts. Mother can't keep a secret.

2. F. 3 yrs. old. Fair. Once while at her grandmother's, her aunt had a gentleman caller. On this, as on other occasions, H. found her way into the parlor in spite of efforts to prevent, and was soon seated on the gentleman's lap. He asked her how long she was going to remain at her grandmother's. She said that her grandmother was making her a black petticoat and that as soon as that was finished she was going home. Once on being asked if she were not a nice little girl, she replied: "Yes, I am acting like a persect little lady, cause mamma told me to." Do not know that it is inherited.

\section{LoQuacious.}

I. $12 / 2$ years old. Dark. German. Talks to any one who will listen, and when he has no listeners, talks to himself. Is bright, and says he wants to learn Latin, Greek and German, and become professor of elocution in some college. Regarded as an annoyance by teachers. who give him no attention unless compelled to do so. Pupils regard hin as a brainless chatterbox. Parents pet him and consider his talking a mark of high intelligence. 
2. F. 4 yrs. old. Fair. Good disposition. Talked continually. Would talk to any one near, and if no one was about, she would get her doll and talk to that, or perhaps a cat, or a picture, and if not to them, then to herself. She often sits by the window, watching the passers-by, and talks to them, although there is no possibility of their hearing her. Neither parent unusually talkative.

3. M. 5 yrs. old. Light. Talks all the time. When playing alone talks to himself as though he had some one with him. Offered him ro cents once to stop talking 5 minutes, but be could not do it. Teased about it. Mother a great taiker.

4. F. 7 yrs. old. Also witty. Told everything she knew to any who would listen. She simply must tell all she knew. One of her mother's friends brought a piece of goods to be made into a dress for the child, saying it was left from her wrapper. L. was cautioned not to tell this. On wearing this dress for the first time, she told her mother that some little girls had admired it very much. When her mother asked her if she had told about the wrapper, she replied, with downcast eyes: "I tell everything I know, don't I?" Father same way.

\section{INQUISITIVE.}

1. M. I2 yrs. old. Dark. Bright. Mania was to find out how things were made, and he was constantly tearing things to pieces and peering into everything with a cover. When he hears any one talking he will at once listen and then begin to question. Something of a sneak in his manner of prying into things. Once looked over a medicine chest, and to satisfy himself, tasted of the contents of all the bottles. Do not know that it is inherited.

2. F. ro yrs. old. Fair. Asks all manner of questions. These usually relate to the person to whom she is talking. She said : "Aint those nice shoes? How much did you pay for them? I ask a good many questions, don't I ?" Does not wait for her questions to be answered. Whines also.

3. F. 8 yrs. old. Light. Nervous. Was continually asking questions about what she saw, wherever she went. Her object seemed to be merely to pry into things. Do not know that she inherits it.

4. M. 7 yrs old. Light. American. Asked a great many questions and wanted to look on the inside of everything. Would sit on the floor for a long time, watching the clock. Some one told him there was a little iron man inside it. One day when his mother was out he took down the clock and was fast making his way into the home of the little iron man. Parents have always tried to answer his questions. They are fine, educated people.

The frank, loquacious, and inquisitive seem to agree in the matter of defective self-control and want of power of inhibition. Weakness rather than strength is suggested in that respect at least. The frank tend to become tattlers, while the loquacious are often nervous, restless, conceited, forward, spoiled, and anxious to be noticed. The inquisitive are too often merely curious.

\section{COURAGF.}

1. M. Light. Never afraid of anything. Thoughtful and careful. When four years old went with his father and some neighbors to rescue a cow from the mire. About II o'clock at night he grew tired and started home. There were no houses along the way, which was, for 
quite a distance, a causeway with water on both sides, and led over a bridge, and by some woods. A neighbor tried to have him stop at his house, but he would not. Was never frightened by stories and the like From mother.

2. F. 6 yrs. old. German. Dark. Happy. Not afraid of anything. Will go into any place at any time of night. Once bitten quite severely by a savage dog. Next day she slipped out of the house and began to torment the same dog. Not hereditary.

3. F. 8 yrs. old. Norwegian. Will go to bed in any room, no matter how dark. Her mother never allowed her to be told any ghost stories or to hear of hell, hence she knows of no fear.

4. F. 4 yrs. old. Fair. Fiery temper. Courage and timidity. Has no fear of animals, such as cows, horses, and dogs. Will walk between their legs. Not afraid of thnnder or darkness. Yet from babyhood would be thrown into a fit of screaming by a feather, or any rasping noise-as a toy squeaker. Cannot be overcome by examination, of course, as she won't go near the object. Normal in other respects. Additional age and reason needed to cure it.

The courageous are usually healthy and strong, both mentally and physically. They are very often quiet and reserved in disposition, as well as obedient and generous. They are natural leaders and therefore respected. In two cases it is stated that ghost, or other such, stories were never told them.

TIMID.

I. M. 5 yrs. old. Fair. Nervous. Exceptionally timid until 3 . Was afraid to stay on the porch while mother was in the house, or in a room alone while mother was in an adjoining room. Afraid of strangers and various animals. Parents carefully guarded against his being left alone and frightened in any way, and he gradually overcame his timidity. Caused by nervousness brought on from measles.

2. M. 6 yrs. old. Americal. Light. Very bright and well formed. Afraid of toads. If he, while playing in the yard, happens to see one, seems unable to move and cries for his mother. Although quite a large boy now, he is still afraid of them. Do not know what gave him this fear and mother says she does not. She has used it to make him come in the house.

3. F. Scotch-Irish. Not afraid of thunder or lightning, nor of any animal except the horse. Always afraid of strangers, especially men and boys. Whel she started to school she went with her older sister and did as she did. Finally she got well enough acquainted to do very well, but whenever straugers came in she would run to her sister. Recites much better alone than in the class. Things that call her into notice are the hardest for her. Do not know about the cause.

Tinidity evidently has a physical basis. It is doubtless true that it can be induced by surroundings, and such cases are reported, but environment produces its effect much more readily on those who are physically predisposed. Signs of this predisposition are nervousness, weakness, and bad health getuerally. There are cases of survival from ancestral influences. Very often the fear has been made use of to secure the enforcement of commands, a practice as dangerous as it is savage and cruel. 


\section{WhINING.}

I. F. 7 yrs. old. Was a delicate, thin child and always whining. Said she did not have as nice playthings as other children and was always treated worse than others. Once when she and her little cousin were at her grandmother's she imagined that she did not receive the proper attention and said: "I am going to cry, grandma," and burst out in a sob. She kept on in a mournful whine until shown all the attention. Treated better than brothers and sisters.

A very limited number of these are mentioned, and but one that is typical. From these, one would infer bad health as a cause. In one case the statement is made that the peculiarity is due to conduct of mother before birth. One is the youngest child. Petting is perhaps common at home. They are not favorites with others.

\section{SPOILED.}

I. M. I4 yrs. old. Has a bright face and always receives marked attention from strangers. Teachers and others were always quoting bis bright sayings. As he grew older he began to shirk his work and grew indolent. Seems to have no ambition. Seems to be father's pet, and brothers and sisters have to do his work. Fxact counterpart of his ambitionless father.

2. M. 8 yrs. old. Entirely spoiled. Will not go to school unless he has such and such a thing. Will not play unless his sister plays with him. Has to be coaxed to do everything. Petted very much.

3. M. 7 years old. Has so many toys that they now have no charm for him. Must have a thing the moment he asks for it. If he says his little sister is or is not to do a thing, she must or must not. Aim of his parents is to gratify his every wish. Neither of them so.

The spoiled are the "only child" in six instances, the "only boy" in one instance, and the "only girl" in one. Thus, aside from the influences which may lead to spoiling after birth, there seems to be a cause at work before birth. They are beautiful, selfish, grumbling, lazy. All are humored and indulged to some extent, while most are to a degree that is suggestive of great ignorance of parents as to sensible treatment of children. They do not get along well with other children and prefer not to be with them. The aversion seems to be mutual.

\section{Giutronous.}

I. M. 3 yrs. old. Never has enough. Will eat as long as there is anything to he had. Father is large, and a large eater, so the boy probably inherits.

2. M. ro yrs. old. Dark. Would always eat something of everything on the table. Eats very fast, swallowing his food slmost whole, yet is the first one to the table and the last to leave it, if possible. Can't place anything before him which he does not like. He seems to be hungry all the time and will be asking for more inside of an hour after meal times. Seems unable to control his appetite. Sometimes eats so much that he can hardly walk. Unlike most big eaters he is thin. Would give him a fixed amount for each meal. Brothers and sisters sometimes tease him. Not inherited. 
3. M. 5 yrs.old. Light. Good disposition. When be came to the table would use both hands, and shovel the food in, as it were. Could not be made to use a knife and fork. Seemed he could not get enough. Was a source of amusement, and laughed at at school.

4. F. I / yru. old. Light. Irritable. Eats more than any other child of this age ever seen. Eats everything a grown person would eat. Is not contented with a full stomach. Eats until uncomfortable Saw her eat two dishes of apple sance, oysters, crackers, milk, and cry for cheese and bananas. Was finally satisfied with candy. She is stuffed with nearly everything and the doctor often has to be called in as result. Parents and grandparents so.

The reports for this group are too few to afford suggestions of any special value. However, it does appear that the gluttonous are likely to be subjects for pathological consideration -that good health is not characteristic. Evidently if disturbed health does not cause gluttony, disorder often results from it.

\section{Ongy Caind in a Family}

x. F. 16 yrs. old. Light. Sober. Only child until 6. Spoiled. My mother often says I was born with a "golden spoon in my moutb" and, as I was the first child, nothing was too good for me. Had the largest room in the house and that literally packed with toys. Everything I wished for was granted. Papa would bring people honie to see me almost every night and even bad my picture printed on his bank checks. In short time I became thoroughly spoiled and was tired of books, toys, games, and every childish amusement. If I did not get my own wey I would cry, kick, and scratch iny nurse. Then iuy parents began to realize they bad indulged me too much. We moved fater to $L$. to live with my mother's friend who had two daughters. I was compelled to share all my things with them. About this time my oister was born and I gradually grew out of my selfish, spoiled ways. Think later treatment right. My association with the two little girls, and the birth of my little sioter, with whom I had to share, cured me. Did not go to school.

2. F. 9 yrs. old. Dignified. Was an old-fashioned kind of girl. If you had talked to her as to others of her age she would have been insulted. Would come into our house, sit down, and talk like soroe little old woman. Never cared to play with children of her own age, and, if she could not find older girls to play with, she would visit the children's mothers rather than play with younger ones. Seems to have been due to heing with older persons. Had spinal trouble when young, was a cripple for awbile and not allowed to play with others for fear of being hurt. Hence did not care for children when older. She was petted a great deal at home and treated as if a great deal older. Disagreeable to an extent and wanted ber own way. Did not go to school.

3. F. I4 yrs. old. Nervous. cannot sit still. Jerks most pitifully when you look at her. Muscles of her face twitch so badly that her face is thereby distorted. Cannot sit otill loug enough to do auything like sewing, playing on piano, etc. Parents let her have her own way, a she gets worse if they do not. Pupils all notice her affiction.

4. F. 3 yrs. old. Fair. Good. Imaginative. Would pley with imaginary children and have imaginary tea parties and games. Had imeginary everything. One day as some of her imaginary friends were supposed to be coming in at the door some oue knocked. She 
cried , "O mamua ! they have come! they have come!" Not allowed to play away from home or with other childreu. Not inherited.

5. M. Io yrs. old. Dark. Not good. Selfish. When playing wants all the best things and the most prominent place. Never thinks of giving anything up unless made to do so. At home has and does nearly everything he chooses. Not a general favorite at school. No heredity.

6. M. Io yrs. old. Light. Selfish, spoiled, andill-natured. Is so selfish that children of his own age will not play with him. Always wants his own way and plays with children much younger than himself. Very ugly to them unless they allow him his own way in everything Children at school will very seldom play with him. Is delicate. Father's mother not selfish.

46 of the 1045 cases are explicitly stated to be of this class, while there are a number of others that obviously are. Thus one out of twenty of the entire number is an "only child ;" a number entirely out of proportion to that found among children generally. "The only child in a family" is therefore very likely to " be peculiar and exceptional."

The general character of these peculiarities is suggested when it is stated that two-thirds of these children belong to the group having disadvantageous traits. I 2 are said to have bad health and 4 are said to have good health, while it appears from other information that at least three-fourths are below the average in health. In fact it would seem that bad health is the rule among such. It appears, also, that the parents, one or both, are below the standard in vitality, and perhaps that sterility begins early with them.

Of those who are of school age 9 do not go to school, while 7 are reported as going. It is therefore probable that quite a large per centage of such children do not go to school at all and that the remainder, for the most part, attend very irregularly. They do not seem to get along well with other children, in the greater number of instances, because they do not understand each other. The "only child" is deficient on the social side. To help himself, however, he commonly resorts to imaginary companions. The devices which they employ to help out in this matter are various and interesting, and suggest somewhat as to the strength of the social instinct.

The greater number of them are "petted," "indulged," " humored," "spoiled," etc. Still there are some exceptions to all the more striking peculiarities here mentioned. There are five respects in which they are different from the ordinary child. They have imaginary companions, do not go to school regularly, if at all, do not get along with other children well, as a rule, are generally spoiled by indulgence, and have bad health in most cases. But as this subject is to constitute a later and separate study, for which a part of the material is already 
at hand and more in course of preparation, it is best not to pursue it further here.

It ought to be mentioned that the "youngest child," the "only boy" and the "only girl" display many striking resemblances to this class, and that quite a number of them are found in the list. They, together with " twins," are to be included in the forthcoming study above mentioned.

It is scarcely possible to collect as large a number of reports as is here represented, any considerable number of which shall be much more than general observations of individuals. A different result was not expected, however desirable it might have been. Yet there have been received a few so comprehensive and admirable in every way, that it was impossible, as it would have been unjust, to subject them to much condensation. One of these is presented below as suggestive of what would constitute wellnigh complete reports. Another, still more complete, will be presented in connection with the "Only Child" study.

F. 35 yrs old. American. Blonde. Nervous. Left eye weak from third year. Unable to keep lid open in bright light. Left side did not develop uniformly in size with the right. Though agile for short periods, strength soon gave out and play with others was therefore not enjoyable.

Had remarkahle memory for eveuts or dates. This was iuherited from father. Was disorderly with own property. Truthful. Disobedient when inclinations clashed with orders. Exceedingly sympa. thetic. Considered selfish by other children, always to ny surprise. Always wanted to use authority instead of acting. Later years have showu that spinal and heart disease must have been latent, and, as nearly as the early feelings can now be analyzed, did not feel able to compete with others in games requiring physical strength and thought it a disgrace to admit illness as the cause. Naturally frank and talkative, but could keep a secret if necessary. Very hopeful when well but other extreme when ill. (Maternal grandfather was a visionary of the most pronounced sort, always planuing and beginning things, but yever finishing. He tried to in rent various things.) Ideals never reached.

Dainty, investigative, exceedingly critical, and restless, but persevering and dogged in a thing attempted. Fond of puzzles. Not imaginative in usual sense. Did not care for poetry. Tried composition once or twice but was discouraged by ridicule of older persons. Have always felt the whole weight of anything with which connected, to the extent of appearing officious to those who do not understand the cause. Mother, whose mother was an invalid for many years previous to her death, took the entire care of a baby brother, who was born miuus the palate, and very delicate, when she was a few months past eleven years of age. At twelve she assumed, with slight aid, the care of three older children, in addition to the baby, providing most of their food and clothing. Have been trained by her to have a great sense of responsibility.

From my fourth year I knew that I was to try to teach. Most of my studying was done at home. Mother said: "You must understand this," whatever the subject, "thoroughly, or you cannot teach it." Do not recall that ever heard or read anything of an interesting or useful nature without thinking of the use which I might make of it 
in teaching. Teaching has been the one passion of my life, except during my seventeenth and eighteenth years, when I hoped to study medicine, but I do not recall much disappointment from being convinced that my physical disabilities would prevent me from making the attempt. Never gave up the study entirely, for saw it could be made useful in teaching.

Did not care for many friends, but was extremely loyal to those for whom I did care. Although conscious of their failings, never allowed myself to admit them to others, or others to name them to me.

If my sister was punished I fought for her until motber had to punish me too. Was saucy to mother (not often intentionally, for was with older people so much that I did not realize the difference), but would have wanted to kill any one out of family who was so to her.

Dislike was cumulative, and a long series of injuries was often unnoticed, but finally some worthless affair would seem to precipitate all and the friendship was at an end.

Was always a good judge of character where preconceived notions did not interfere.

Mother's marriage was unfortunate, my father having been a spoiled child, and given to all forms of dissipation. When I was four or five years old my mother's brothers took us away from him. I somehow felt there was something disgraceful about him, and when other children asked me where he was, I ran away and hid without answering them. I stayed and cried until they tired of waiting for me. This I never told my mother, or any one until recently. After I was twenty years old I fainted several times at the unexpected sight of an intoxicated man. After beginning teaching, and when the teaching of temperance in the schools came up, I fainted several times in teachers' meetings in spite of all efforts at control. Have succeeded in gaining control in that respect now.

My mother was intensely sensitive and introspective, and my being with her so much and so little with others, has caused me to be like her. Had a morbid sense of responsibility, and expected that people were going to be very careful of some of rny feelings. At eleven went to boarding school, as my health was too delicate to run the risk of ordinary school exposure. Suffered intensely from physical illness and the mistreatment of other pupils. My reserve on the play-ground was attributed to my pride in my scholarship, which was merely a matter of memory and custom, not to nyy illness, of which I was ashamed, or to the fact that $I$ avoided intimacy with other children lest they should ask me about my father. When I was ten we moved to a place where my mother's relatives lived. Of course people asked about him. I used to say I did not remember him, and then, from sheer nervousness, cry. That usually stopped questions, and, during my eleventh and twelfth years, while at school, I profited by such methods.

Arithmetic was hard for me, and we had poor teaching. I formed the habit of dreaming out the problems. An uncle, uny mother's brother, did the same thing, but I do not know whether be did it deliberately, as I did, or not. When twenty, and again when twenty-five, I more than once dreamed the solution to algebraic and geometric problems and got up in my sleep and wrote them out as neatly as if I had been awake, finding them so next morning. It is almost impossible to let things alone which I have once undertaken, though to this day the ones who think they know me best insist that it is for the sake of having my own way. I know that it is not. Am the same for disagreeable tasks as weli as for those I like. If I dislike certain work I compel myself to master it, till the manner of doing is a pleasure in 
itself. Until within a few years I could work through almost any amount of physical pain. The more pain I felt, the more I would laugh and joke. Physical endurance is a characteristic of both families I know little in detail of my father's family. He was a very liard drinker, but rarely became unsteady. Was phenomenal in that respect. At the age of $22 \mathrm{I}$ had a tooth extracted and swooned. The pliysician and dentist could not revive me for some time, though they both told me they gave me eight ounces of strong brandy. I then walked home My sister, two and a half years older, cannot take a tablespoonful without affecting her head, nor can my mother. It is very difficult to put me under infuence of gas, ether or chloroform, and equally hard to revive me after it has been done. I am not apt to be nauseated, though the heart action is weak. Have frequently been given large quautities of brandy and whiskey by physicians to break up chills, and to aid in recorery from attacks of angina pectoris, or succeeding hemorriages Every one notices the amount I can take without perceptible effect Some have auggested that it may be the result of direct heredity, but $I$ have never found anything in my reading to confirm my opinions. It was the first dose that was noticed. No remedy seems to have the normal effect on me. It is peculiar to me alone in the family.

Was extremely quick tempered, and downright ugly when aroused. Mother's paterual grandmother and aunt were considered ugly in temper. The grandmother's health and the aunt's husband may have accounted for their dispositions in later life.

My mother's method of governiug ne was to tell me that I was like some one whom I thoroughly disliked, when she considered me naughty, and to hold up people whom she considered models, as patterns. I deem it a poor method. Children are quick to discover anws in such weak methods, and I know that I lost all confidence in her judgment.

\section{STatistical, Analysis.}

The types have been divided into three groups (see tables III aud IV), on the basis of the worth to the individual, of the various peculiarities. They are the advantageous, the neutral, and the disadvantageous. In the first are found the tall, the heavy, the stout, the strong, the agile, the deft, the beautiful, the clean, the generous, the sympathetic, the buoyant, the orderly, the obedient, the courageous, and those having keen sense powers. They represent 427 children, of whom 270 , or .629 , inherit the peculiarity, 45 , or .104, do not, and II2, or .265 , are not accounted for.

In the second are the buffoons, the frank, the loquacious, the imaginative, the inquisitive, the dignified, the teasers, the silent, and the dainty. Of the 126 of these there are 57 , or .456 , who inherit, 23 , or . 176 , who do not, and 46 , or .368 , who are not reported.

In the third belong the dirty, the ill-tempered, the small, the timid, the whining, the disorderly, the disobedient, the cruel, the glattonous, the selfish, those with sense defects, those having bodily weakness, the ugly, the nervous, the deformed, the spoiled, the birth-marked, the liars, and the clumsy. 
There are 448 of these; 126 of them, or .28 J, inherit, 206, or 457 , do not, and 116 , or .33 , are not accounted for.

The greatest amount of inheritance, .629 , is found in the first group, the next greatest, .456 , in the second, and the smallest amount, .281 , in the third. The three groups show a descending scale of inheritance, beginning with the advantageous, passing to the neutral, and ending with the disadvantageous, there being a difference of $3+7$ between the .628 of the first group and the .281 of the third.

It is proper to add at this point that this part of the study was undertaken with the expectation that one of the conclusions arrived at would be the greater connection between disadvantageous traits and inheritance. That a radically different conclusion has been arrived at can, therefore, hardly be in any degree ascribed to a prejudice in its favor.

The general validity of the percentages in Table III, may be objected to, however, on the ground that mental traits are included along with physical, and that it is impossible to tell with much certainty what is due to inheritance, and what to environment. It is generally recognized and admitted that mental diseases of parents show a marked tendency to appear in the same form in offspring, following the law of similarity. This element of uncertainty is easily eliminated by omitting the mental peculiarities from groups 1 and 3 of Table IV, and retaining only such as are fundamental and physical. T The first group, as thus limited, includes the tall, the strong, the stout, the heavy, the agile, the beautiful and those with keen senses. The third, so limited, includes those with sense defects, the ugly, the nervous, the deformed, the birth-marked and the suall. (These two new divisions coustitute groups 4 and 5 of Table IV.) In the fourth there are 261 , of whom 174 , or .666 , inherit, 24 , or .09I, do not, and 63 , or .24I, are unaccounted for The fifth contains 260 , and of these 64 , or .246 , inherit, while 137 , or .526 , do not, and 59 , or .226 , are not accounted for. Thus we have an increase in the first group, as thus modified to eliminate the confusing element, of .033, while in the third group, as so modified, we have a decrease of .04.

The great part which imitation plays in fixing of mental traits renders it unsafe to offer any data for conclusions as to the transmissibility of mental qualities.

The data for determining the relative degrees of influence of each parent is more satisfactory. In some cases, however, the parent through whom the trait was acquired has not been mentioned. In others the peculiarity is said to have come from an uncle, an aunt, or a graudparent, but no information is given

See Table IV, groups 4 and 5 
PECULIAR AND EXCEPTIONAL CHILDREN.

\begin{tabular}{|c|c|c|c|c|}
\hline \multicolumn{2}{|c|}{ 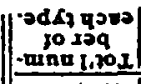 } & \multirow{2}{*}{ 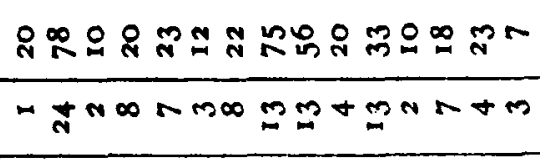 } & \multirow{2}{*}{$\frac{\pi}{4}$} & \multirow{2}{*}{$\frac{m a m n}{n m a t}$} \\
\hline \multirow{3}{*}{ 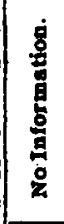 } & 忠 & & & \\
\hline & 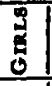 & 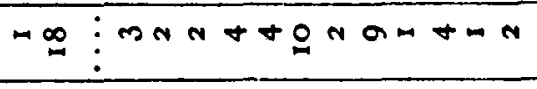 & $\ddot{b}$ & $:-\infty$ \\
\hline & 呙 & $\vdots 0 N \backsim n m+a m n+m m-$ & $g$ & $\ln \pi$ \\
\hline \multirow{3}{*}{ 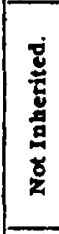 } & 点 & $\vdots+\pi$ amt+omn & \& & $-\vdots \vdots n$ \\
\hline & 3 & : & से & m $\vdots+\infty$ \\
\hline & 渵 & $\vdots \vdots \vdots \vdots$ : & 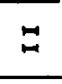 & $\vdots \vdots \vdots-1-$ \\
\hline \multirow{3}{*}{ 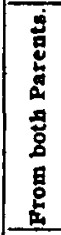 } & 要 & 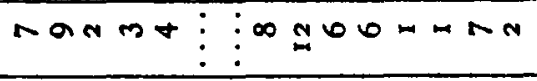 & 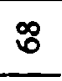 & $\vdots$ « \\
\hline & 章 & 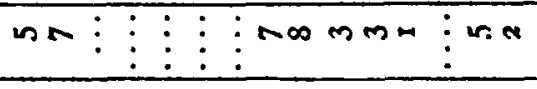 & 7 & $: \vdots \vdots \vdots \vdots$ \\
\hline & : & 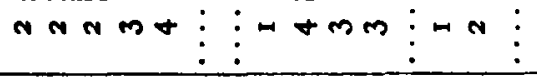 & $\pi$ & $\vdots$ N \\
\hline \multirow{3}{*}{ 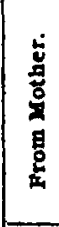 } & 范 & $8 \pi n m a n d n$ & 8 & - 2 n \\
\hline & \begin{tabular}{c|}
9 \\
0 \\
0
\end{tabular} & HエNMNM & $\pi$ & $\vdots \vdots \vdots+\vdots$ \\
\hline & 密 & ๓๐: $\vdots \vdots$ : & in & - $\sim \vdots \vdots \vdots$ \\
\hline \multirow{3}{*}{ 岕 } & 葍 & $m \approx m$ m n $\forall m a m m+n m-$ & $n$ & $m: n n$ \\
\hline & 范 & nonmm! nom nnm & $\approx$ & $\vdots \vdots$ nn \\
\hline & 菖 & A 4 4 4 & $\stackrel{\infty}{N}$ & $m: n-$ \\
\hline \multirow{3}{*}{ 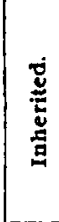 } & 䔰 & 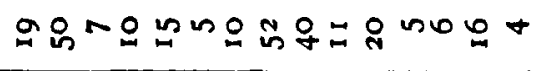 & $\frac{4}{5}$ & no mao \\
\hline & 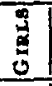 & N & $\stackrel{2}{2}$ & のールナ \\
\hline & 品 & nmmo & $a$ & $\pi n \pi d n$ \\
\hline & & 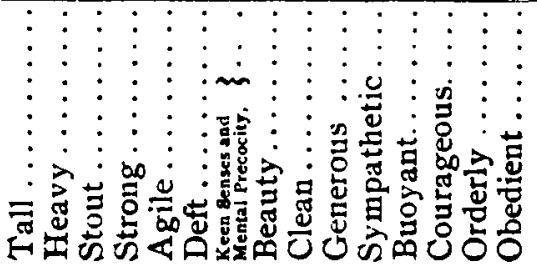 & 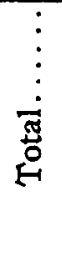 & 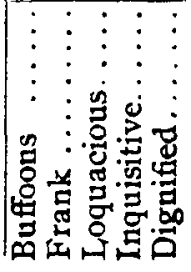 \\
\hline
\end{tabular}


PECULIAR AND EXCEPTIONAL CHILDREN.

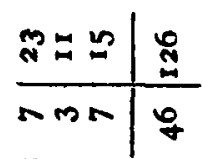

nMN

\begin{tabular}{r|r}
\hline$n+\infty$ & 8 \\
\hline$n n$ & $n$ \\
\hline
\end{tabular}

| 8 ถี ニ

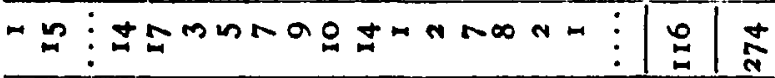

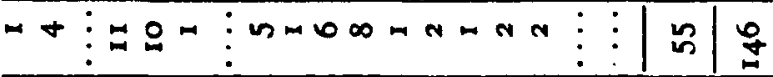

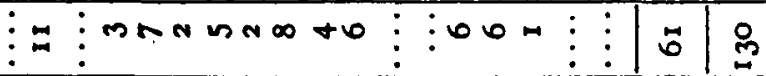

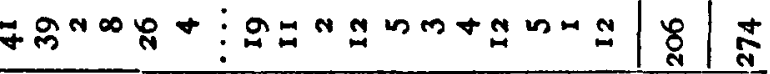

सूNのミN

ก

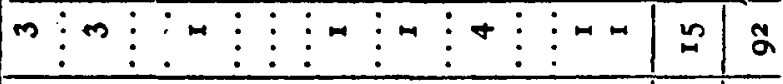

๓

$\vdots \vdots \vdots \vdots \vdots \cdots \vdots \vdots \vdots \vdots \vdots \vdots \cdots \vdots \vdots \vdots \cdots|\sim| r \mid ⿰$

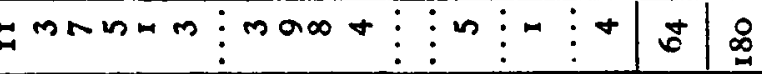

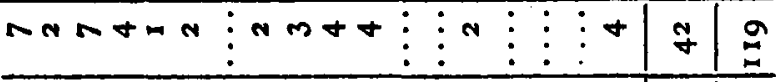

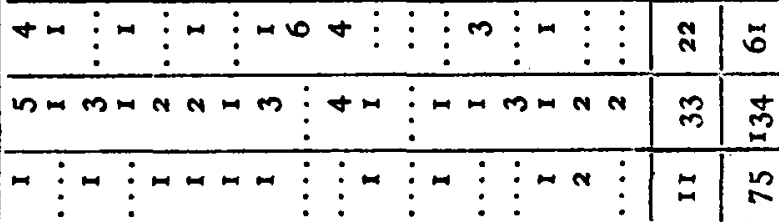

+นn-m-

A

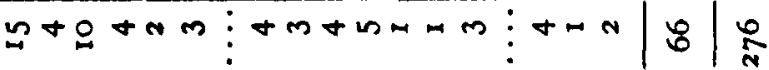

a+unmmm+Nom

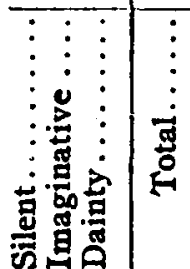

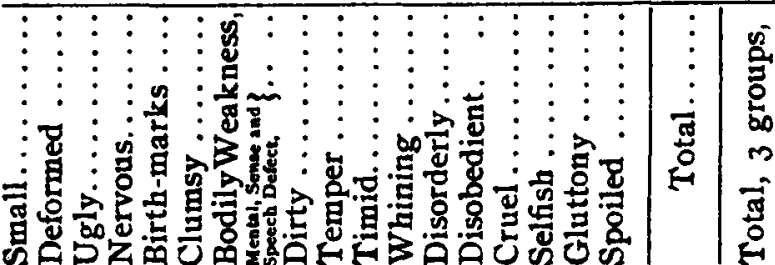




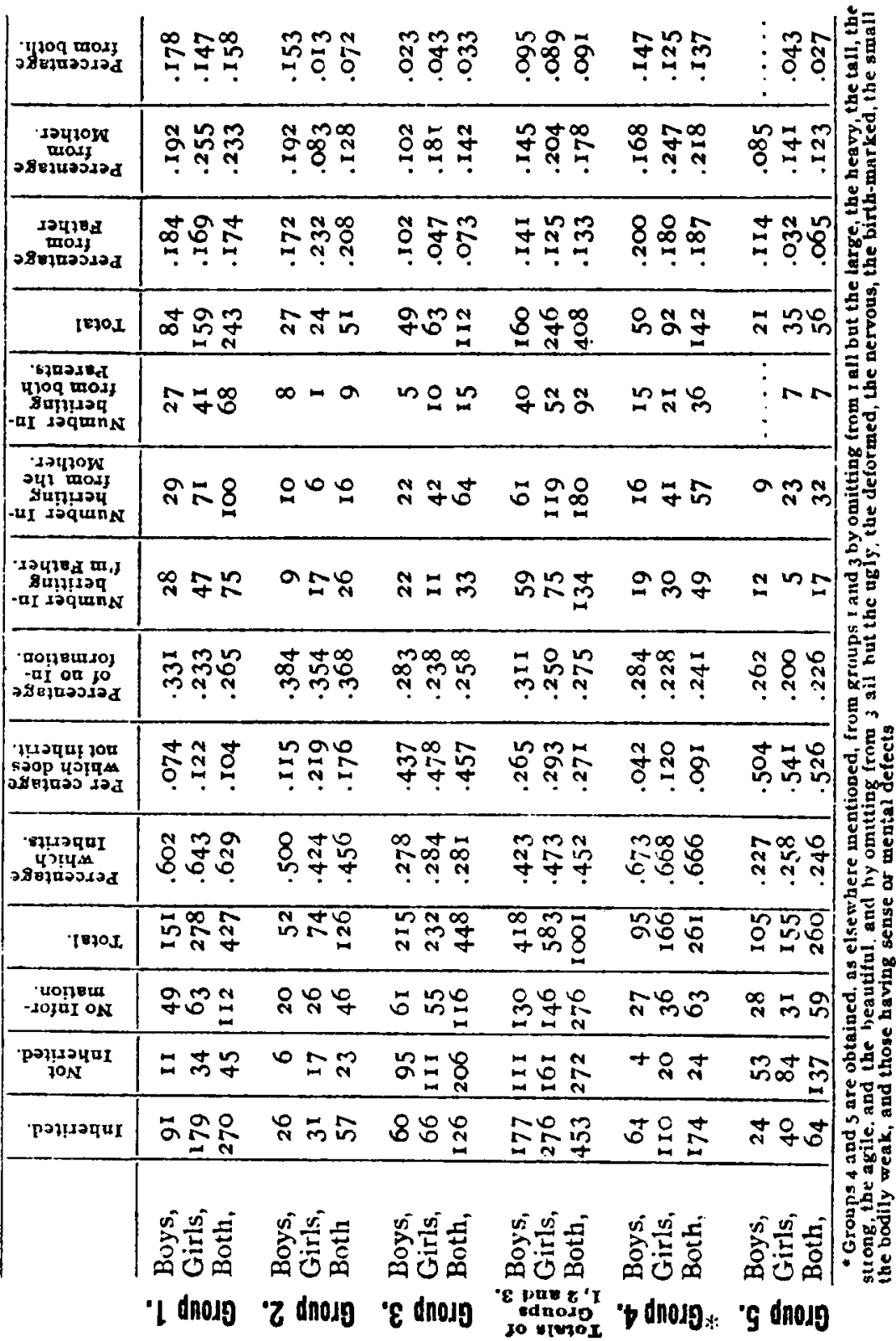


as to whether it was on the paternal or maternal side. So it happens that the amount of inheritance from "father," "mother," and "both parents," does not equal the total amount of inheritance reported. The difference, though, is very small, and is easily obtained in each case from the tables, if desired.

In group I of Table IV-75, or .174, inherit from the father, 100 , or .233 , from the mother, and 68 , or .158 , from both parents. In group $2-26$, or .208 , inherit from the father, 16 , or .128 , from the mother, and 9 , or .072, from both parents. In group $3-33$, or .073 , inherit from the father, 64 , or .142, from the mother, and 18 , or .037, from both parents. Of group 449 , or .187 , inherit from the father, 57 , or .218, from the mother, and 36 , or .137 , from both parents. In the fifth group 17 , or .065 , inherit from the father, 32 , or .123 , from the mother, and 7 , or .027 , from both parents. Of all the cases reported 134, or .133 , inherit from the father, 186 , or .178 , from the mother, and 92 , or .091, from both parents.

Of the 583 girls -276 , or .473 , inherit, while of the 418 boys177, or .423, inherit. There is, therefore, a percentage of .05 in favor of the girls. Of all the girls-75, or .125, inherit from the father, and 119 , or .204, from the mother. Of all the boys59 , or .I4I, inherit from the father, and $6 I$, or .145 , from the mother. Decidedly more of the girls who inherit from but one parent, inherit from the mother rather than the father, while on the other hand the inheritance of the boys from the paternal side is slightly less than that from the maternal side.

The nationality is not named in all instances, but there are roo cases in which it is named as non-American. Twelve different nationalities are represented in this group of 99 nonAmericaus. Twenty-five of the 99 are Irish, 24 German, 13 English, and 10 Scotch. Thirty-one of them are found in group $I$ of Table IV, 18 in group 2 , and $5 I$ in group 3 . Of the fiftyone in group 3,20 are Irish, 7 German, and 7 English. In group 2 there are two who come from intermarriages, ScotchIrish and English-Irish. In group 3 there are six children from intermarriages. Two of the six are Swede-Irish, one each French-Indian, Polish-Dane, German-English, and FrenchEnglish. Five of these belong to the "cruel" children. Let it be recalled that there are 428 children in group 1,125 in the second, and 478 in the third. We thus see that over half of the non-American element is found in the group having disadvantageous traits, which constitutes about $\frac{2}{5}$ of the entire number of cases reported.

The great variety of terms used to describe temperaments renders any comparative estimate of their significance of little value. It is plainly observable that there is an accumulation 
of terms denoting bad temperamental conditions in the last one of the three groups of Table III.

Sixty-four of the boys have dark complexions, I05 are light, 3 are said to be muddy, 3 sallow, 3 medium I sandy, I red, I yellowish, and I "between." 2 ro of the girls are light, 70 dark, 5 sallow, and one each medium, clean, pink, transparent, pale, olive, yellow, and red.

\section{INTERPRETATION OF DATA.}

Inheritance of Good and Bad Traits. According to these reports advantageous traits are inherited more than twice as frequently as disadvantageous ones.

Perhaps it may be urged against this that the persons reporting the various types were influenced in many cases by reason of family pride or friendship, to give undue importance to the beredity in reporting good traits, and to minimize or leave it out entirely, in reporting undesirable ones. That this might be done under such circumstances is possible, but that it was not to any great extent in these reports, is evident from the following reasons: In the first place by far the larger number of children described are neither friends nor relatives of the one reporting, as is apparent from a reading of the material. In the second place a large portion of the remainder are reminiscences, and in these, quite as frequently as in the foregoing, heredity of bad traits has been named. Likewise, when desirable qualities have been described, there are quite as frequent denials of inheritance as in the case of others. The same may be said of friends and relatives who have been described in a comparatively small number of instances. Indeed, it would seem, from the fact that defects and faulty development stimulate much more strongly the effort to account for their existence than do those peculiarities which do not fall below the average of normal development, that the prejudice would be in favor of the disadvantageous qualities. Besides, there is uniform evidence of sincerity and fidelity in the reports. The evidence which the reports themselves have to offer, added to what is so well known about the preparation of the greater part of the material, leaves little doubt as to the general reliability of the percentages upon which the conclusion here involved, rests. We are driven, therefore, to find explanations which are in harmony with the conclusion.

It will hardly be denied that the strength of inheritance in a given case is indicated by the degree of similarity manifested between parent and offspring. and that the less pronounced the similarity, the weaker the inheritance. Dissimilarity in transmission is the result of a weakening of the ancestral stock and implies degeneration. Again, it will hardly be denied that 
when procreation takes place under normal conditions, the influence of the latest parents will predominate over that of any preceding pair of ancestors. When not so, degeneration has begun. This variation need not proceed very far betore dissolution comes in the form of sterility or death. The unifying character of the immediate parental force, which should be strongest in its conserving potency in bringing together and holding the various elements that enter into the life of the new being, is weakened until some other ancestral strain asserts itself. Maudsley has described this process as the " unkinding of the species." "Féré has said : "If the degenerate fails to give origin to beings that resemble him, it is not because he has acquired the special faculty of transmitting characteristics that do not belong to him, but because degeneration is the dissolution of heredity."

Disease and defect usually undergo modification in transmission-if we may call such transmission-following the law of dissimilarity. Health and healthy peculiarities are not, at least to such a degree, subjected to such modification, and follow the law of similarity in transmission. If degeneration is the dissolution of the ancestral force, and if one of the evidences of degeneration is variation from the ancestral types, we should expect to find that the more pronounced degeneration is marked by the more pronounced variation, or, stated in another way, by a greater dependence on environment. There is a diminished power to control environment, to choose that which is helpful and to avoid the harmful. Self-dependence, self-determination, are lessened. Environment being a much more variable and uncertain factor than heredity, which selects and conserves in accordance with an inner law, it is to be expected that the offspring of degenerates should show more variations.

It seems unfair to say that an individual inherits disease. The general effect of diseased parentage is most likely to be manifested in children of insufficient vitality, and, therefore, of a limited power of resistance to degenerative influences. Upon such, environment has the greatest influence, and may easily fix disease. It is possible, through a long, slow, difficult process, for the degenerate stock to regain the normal condition. On the other hand a very small part of the life of a single generation is sufficient to undo what has required many generations of development. But if many generations, under improving conditions and the better health resulting therefrom, are necessary to capitalize the ancestral force so that advantageous traits may be transmitted, it ought much less to be expected that the degenerate, with diminishing ancestral vitality behind him, to-

1 "Morbid Heredity," Féré, Pop. Science Mo., July, '95, p. 396. 
gether with the necessarily unfavorable surroundings, shall acquire in a few generations the power to reproduce in his offspring a peculiar disease.

To summarize the suggestions of the foregoing statements, we are influenced to regard the .629 of inheritance of desirable traits and the $.28 \mathrm{I}$ of undesirable ones as approximately expressive of the true condition of things. First, because healthy and vigorous parents with good ancestry may, and often do, beget defective and unhealthy children. Secondly, because parents who are not vigorous or healthy require generations of improvement to produce healthy children.

A few sentences from Maudsley are interesting in this connection. He says : 1 "Degenerate or morbid varieties of civilized races evince a similar incapacity of procreation; sterile idiocy bring the natural termination and extinction of degenerate rarieties of the human kind. In vain might the most curious despot attempt to propagate a race of idiots.

Is it not easy to conceive that, without being so incompatible as to actually refuse to combine, the germ elements may be so far unsuited to one another that when they combine they do so in a half-hearted way and produce an unstable compound? .

It is the opposite of that movement of progressive specialization and increasing complexity of relation with the external which marks advancing developinent."

2 "There is the rapid undoing of what has been slowly done through the ages; the disruption and degenerate manifestations of faculties which have been tediously acquired; the resolution of what has been the gain of a long process of evolution; the formless ruin of carefully fashioned form. We are sad witnesses of the operation of a pathological law of dehumanization in producing dehumanized varieties of the human kind."

Likewise Féré : 8 " The want of resemblance in descent ob. served in pathological and teratological families evidences the want of embryogenic energy which is so accentuated in those families as to end in sterility in a few generations. . . . . Degeneration in general results from embryogenic troubles which are reduced, as a whole, to troubles of nutrition. . . . By degeneration should be understond the loss of the hereditary qualities that have determined and fixed the characteristics of the race. . . . The dissolution of heredity, which may be realized either by the introduction of strangers of too different races, or under the influence of native causes of degeneration, is marked both by physical unlikeness and by the psychical and moral ones that necessarily accompany them. The social dis-

2 "Pathology of Mind," Maudsley, p. $94 \mathrm{seq}$.

z "Pathology of Mirsd," Mandsley, p. 205.

3 "Morbid Heredity," Fére, Pop. Science Mo., July, I895. p. 395 ser. 
cords that spring up among people like those that so often divide the families of degenerates, taken together, constitute a manifestation of the dissolution of heredity ; their source is in a biological fact. . . . L Less and less deficient children may be observed to be horn in a family of degenerates as the biological conditions of the parents improve. . . . . Generation is, as a whole, the result of an excess of nutrition."

The procreative power needs to be nurtured, accumulated. It is not something that may be neither added to nor subtracted from, performing its work whenever the sexual act is consummated, by virtue of some innate and unmodifiable potency. It needs to be aggressive and positive. The greater the vitality behind it, the better the result, the more perfect the reproduction. Stating it from the other side, Shuttleworth ${ }^{1}$ has said: "Mentally feeble children are often the offspring of highly neurotic parents, sometimes of highly cultured persons, exceptionally bigh in particular directions. It would seem, indeed, in some cases that the parents have themselves expended so much of their nervous energy that they have little left to transmit to their offspring ; and familiar instances will occur to every one of distinguished men and women afflicted with children whose mental endowments are below the average.

"Mental feebleness is in some few cases the result of feeble health, and with improved physical conditions the mental intpairment may gradually disappear."

Although there are few or no reports of direct investigations along this line, there are some that have a very important bearing, indirectly. ${ }^{2} \mathrm{Dr}$. Carlsen, of Copenhagen, read a pamphlet at the International Congress of Hygiene and Demography, held at London, in August of $189 \mathrm{I}$, setting forth the results of statistical investigations with reference to idiots and feeble minded persons among the Danes. He says : "The illegitimate imbecile children amounted to $5 \%$ of the total number of imbeciles, while about $10 \%$ of all births have been illegitimate in Denmark during a long period of time. As it is probable that the number of the imbeciles overlooked or forgotten in the counting is larger within the class of legitimate than within that of illegitimate children, we incline to the supposition (even if proper attention is paid to the fact of the greater rate of mortality for illegitimate children) that imbecility is scarcer among illegitimate than among legitimate ohildren; which accords very well with the fact that, the more malignant forms of imbecility cocur less frequently among the illegitimate children." It would hardly do for an explanation of this to assume

\footnotetext{
1" Mentally Deficient Children," Shuttleworth, pp. 39, 40.

2Referred to by Ieffingwell, "Illegitimacy and the Influence of Seasons upon Couduct." p. 77.
} 
that the parents of such children are more favored or better circumstanced, and that therefore the pre-natal life of the illegitimate offspring is necessarily better than that of other children. Statistics show that the death rate of such children, after birth, owing ta influences in no way connected with bad health is much higher. Their greater freedom from ailmerits and diseases can therefore hardly be attributed to influences that act after the beginning of the embryonic life; it must be due to the presence of greater vitality in the parents in conception, which we are warranted in assuming because the act is cousummated in defiance of both civil and social law.

The investigation of M. A. Pinard, "A Propos Du Development De L'Enfant," reported in the Revue Scientifique for January, 1896 , should be noticed here, though it has special value as showing the greater influence of the mother in determining the future well-being of the child. His studies are based upon the data collected from the asylums and refuges in Paris for abandoned women about to become mothers. These women are received at these institutions and cared for during the period of confinement. He found in the cases of 500 women who had worked up to almost the very moment of accouchement that the combined weights of the children amounted to $I, 505,000$ grammes, 3,010 grammes per infant. 500 women who had sojourned at the refuge at least ten days before confinement had given birth to children whose combined weights amounted to $1,645,000$ grammes, 3,290 gramme sper infant, or a total excess over the entire weight of the first 500 , of 140,000 grammes. 500 who had sojourned at another hospital gave birth to children whose combined weights amounted to $1,683,000$ grammes. 3.366 grammes per infant, or a total of 178,000 grammes more than was found for the first group. That these differences a re not due to differences between groups of women cared for at the three refuges is proven by other data which are too extended to review here. The explanation has other significance. Suffice it to say that the number of days that elapsed between conception and delivery is smaller in the first group, premature or early births being more common there. To be sure greater weight of body is not in a specific case necessary evidence of better health, but it is, generally speaking, a sign of better nutritional conditions during the intra uterine period. Or, in Pinard's words: "If the infants of those who have had repose are larger than those of the wonen who have not, it is simply because their intra uterine life has not been troubled, and because their incubation has been perfect. They are brought forth because they are ripe for the extra uterine life. In the case of the others, expelled prematurely, the overstrain is the stroke of the wind which causes the green fruit to fall." 
The inquiries of Dr. Alexander Graham Bell and of Edward Allen Fay, into the results of deaf marriages in the United States, furnish more conclusive evidence of the general validity of the conclusion under consideration. Through their efforts, information concerning the hearing of about all the offspring of marriages of the deaf in this country has been obtained. Fay's ${ }^{1}$ reports are the more comprehensive and show a total of 8,504 persons married, one or both of the partners being deaf, 7,277 are reported as deaf, 892 as hearing, and 335 are not reported whether deaf or hearing, that is 85.5 who are deaf, I0.5 who hear, and $4 \%$ who are not accounted for. There are 3,497 marriages, one or both partners being deaf. Of these, 300 , or $8.5 \%$, resulted in deaf offspring. 588 deaf children, or 8.6 of all children, were born from these marriages. Of hearing children as a result of these marriages there are 5,09I, or .75 of all. There are 1,103 , or .162, not reported as either deaf or hearing. The total number of children from these marriages is 6,782 . The author thinks it probable "that 813 (of the 1,103 unreported) are hearing, from the fact that that number has never turned up at any of the deaf schools, while 290 of them are still-born or died before the matter of their hearing could be known." Thus we see that of the 6,782 children from these marriages, in which one or both parents were deaf, it is hardly probable that more than .086 are deaf. But let it be assumed that all of the $\mathrm{r}, \mathrm{IO}_{3}$ children that are unreported on, were deaf, we still have .75 of all who are not deaf. This extravagant allowance of .25 of deafness does not equal the .286 found for group 3 of Table I. It should not be forgotten that one of the classes of defects represented in that group is that of the senses.

Again, Fay finds 2,377 marriages in which both partners were deaf. 220 of these, or .092, resulted in deaf offspring. There were 599 marriages in which one partner only was deaf. Of these, 75 , or .1 25 resulted in deaf offspring, or .033 more of the marriages in which one partner only is deaf than of those in which both are deaf resulted in deaf offspring. If, however, our conclusion is wrong, we should expect to find that something like twice as many of the marriages in which both partners are deaf as of those in which only one is so, would result in deaf offspring.

Furthermore, 359 , or .151 of the marriages, both partners deaf, are sterile, while only 68 , or . I I3, of those in which one partner only is deaf, are so. Of the 102 marriages in which

"See "Marriage of the Deaf in America." American Annals of the Deaf, Jan., Feb., April and June, 1896. 
one partner is unreported whether deaf or hearing, 7 , or .068 , are childless. Of all the marriages, 434 , or $14 \%$ are sterile.

Williams, ${ }^{1}$ of the American Asylum, Hartford, Conn., reports statistics of 590 marriages of the deaf. He found 283 , or nearly half, of these were sterile. We are led to conclude, therefore, that the amount of sterility, and that the number of still-births and early deaths among the deaf are abnormally great, all of which are a sure sign of degeneration. Degeneration, however, marks the decay of hereditary force.

No doubt it could truthfully be urged that some deaf parents purposely avoid having children, either because of their greater inability to provide and care for them, or because they fear that those born to them might have their own defect, but this would account for only a small part of the difference. We must conclude that sterility, still-births, and early mortality, are of kindred origin, and originate in the diminished vitality devoted to procreation, of which diminution, in most cases, deafness is but one of many signs. Fay says: " "Less than one-tenth of one per cent. of children of hearing parents are deaf, in all probability. Deafness, it is true, is neither a physical anomaly nor a disease, and such expressions as transmitted deafness, inherited deafness, etc., are inaccurate and misleading. When deafness of the parents appears in the offspring, what is really transmitted and inherited is not deafness, but some anomaly of the nervous system or the tendency to some disease of which deafness is but the result or the symptoms."

In another place he quotes Sedgwick, ${ }^{8}$ " On Sexual Limitation In Hereditary Disease," as follows: "The fact that a larger number of deaf children are, or appear to be, born to parents only one of whom is deaf, than when both are, may be due to excess having reversed the action of some natural law in development."

The degenerative tendencies present in the deaf and appear still more striking when we note that only 2.56 children are born per parent. If we accept Newsholme's statement that $15 \%$ of all the children born in England and Wales die before reaching the age of one year, as fairly representing the death rate in other countries, it is perfectly clear, allowing for the deaths that would occur before the reproductive age is reached,

1 "Hereditary Deafness-A Study." Job Williams. Science, Vol. XVII, p. 76 .

"Marriage of the Deaf in America." Fay. American Annals of the Deaf, Feb., 1896, p. 87 .

${ }^{3}$ British and Foreign Medico-Chirurgical Review, London, Vol. XXVIII, p. 204.

"Vital Statistics," A. Newsholme, p. ro4. 
that the deaf would soon disappear, as a class, from natural causes, if not added to from other classes.

Again it is important to notice the increase in amount of sterility in passing from the marriages in which deafness is less pronounced, to those in which it is most so-those in which both partners are congenitally deaf. Of the 2,377 marriages, both partners congenitally deaf, 359 , or . $15 \mathrm{I}$ are sterile. Of 599 marriages, one partner deaf, the other hearing, 68 , or . I I 3 , are sterile, while of the ro2 marriages, one partner deaf, the other unreported whether deaf or hearing, 7 , or .068 are sterile. It seems impossible, then, to avoid the conclusion that deafness has its origin in, and suggests degeneration of, a more fundamental sort than is usually associated with deafness. Let this be connected with the fact that .033 less of the parents who are both congenitally deaf, than of those, one of whom is hearing and the other deaf, beget deaf offspring, and we have suggested in an emphatic way, the explanation already offered for the greater liability to transmission of desirable traits, viz., that increasing degeneration is accompanied by decreasing potency of the reproductive powers, less and less of the ability to fix the character of the offspring. It is the triumph of environment over heredity.

It is significant that such defects as do appear to be transmitted in their likeness are such as are not incompatible with approximately normal health. Some of them may be said to originate in excessive growth, at least misdirected growth. Such are supernumerary toes, fingers, or teeth, premature grayness, baldness, plurality of births, color blindness, hair lip, squint, etc. The degeneracy implied in these is not sufficient to lead to the extinction of the stock before the peculiarity gains enough strength to be registered in the hereditary force.

The phenomena of vigorous children from parents who are not so, is most reasonably accounted for on the basis of reversion.

Decline has not proceeded far enough to injure remoter ancestral strains in the stock, and the strongest of these asserts itself at the opportunity presented by the weakened vitality of the late parents. Nature is not therefore unkind. It works for the better so long as its resources are unexhausted. There is a power in it which makes for good.

Father and Mother. The influence of the mother in transmitting peculiarities is greater than that of the father; is greater for girls than for boys and about equal to that of father for boys.

The greater intimacy between the life of the mother and that of the child suggest the necessity of this conclusion. It is not probable that the conscious efforts of the mother during pregnancy are sufficient to fix new and desirable qualities of character in the offspring, qualities not implied in conception, but it 
is possible to nourish and strengthen those already there. On the other hand, it is possible to produce almost any degree of deformity or imperfection, from the very slightest to that which is incompatible with life. The conclusions of Pinard, already referred to, are pertinent in this connection. If, as he shows, a few days of judicious treatment near the end of the pre-natal period can produce such marked effect for good on the child, it is certainly not unfair to expect so much from it when it extends over the whole period.

Williams's report on the 590 marriages of the deaf, elsewhere referred to, shows that with congenitally deaf fathers and adventitiously deaf mothers, $5.7 \%$ of the children born are deaf, while with congenitally deaf mothers and adventitiously deaf fathers, $13.7 \%$ of the children are born deaf. When the husband is congenitally deaf and the wife hearing, $12.5 \%$ of the children are born deaf, but with the conditions reversed the result is $18.18 \%$ of deaf children. The greater influence of the mother is apparent in all his percentages.

The ages at which parents beget children is of interest here. Marro has studied the age of fathers at time of conception, among the criminal class, and has compared it with that of fathers for certain other classes. $\mathrm{He}$ divides them into three groups on basis of age at time of conception. Those under 25 constitute the first group, the immature; those between 25 and 40 constitute the second group, the mature, and those above 40 form the third or decadent group. Speaking of a diagram which he has employed to illustrate Marro's figures, Havelock Ellis says : "It will be seen that the largest proportion of immature parents is among the class of thieves, although among the insane the proportion is still larger. More remarkable is the abnormally large proportion of criminals with parents belonging to the period of decadence. It is most marked among the murderers, $52 \%$ of whose fathers had passed the period of maturity ; but it is very large also, exceeding the insane, among those convicted of assault and wounding, and among sharpers. Sexual offenders have the largest proportion of mature fathers, the smallest of youthful fathers. Suspecting that among idiots a very large proportion of elderly fathers would be found, I applied to Dr. Langdon Down, who has kindly gone through the notes of one thousand cases and confirmed this suspicion. He finds that in $23 \%$ of the cases there has been a disparity of age of more than ro years at the birth of the idiot child, the father in nearly every case being the elder, and that in many cases this disparity has reached more than 25 years.

"It is interesting to compare these results with those of Korasi, director of the Hungarian Statistical Bureau, on the ordinary population. He has investigated 24,000 cases, and found that 
the children of fathers below $=0$ are of feeble constitution, that fathers aged from 25 to 40 produce the strongest children, and that above 40 fathers tend to beget weak children."

Inasmuch as the period of reproduction is, as a rule, shorter with women than with men, it would seem that the age factor plays a more important part in connection with the father. However this may be, it is true that the first and the last born are, much more often than others, both mentally and physically defective. For the last born it is no doubt purely a result of age, while with the first born it may come from the immaturity of the parents, or simply from the fact of being the first born. This point will receive fuller consideration in the report on the forty-five or fifty only children in families found among the various types here studied.

Boys and Girls. It appears that girls are more likely to inherit than boys, and from the mother rather than the father. Girls also seem to be slightly favored in transmission of desirable traits.

This difference in favor of the girls may be attributed in a degree, perhaps, to the fact that the greater number of persons reporting the cases here studied, are females, who might be supposed, by reason of their more intimate knowledge of, and association with, their mothers, to give undue prominence to her influence and too little to that of the father. Also it should be remembered that about one-third more of the cases reported are females than males. It would not, therefore, be wise to attach anything more than a suggestive value to the relations which the percentages express. They would have more undoubted value if they were derived from a study of a much larger number of reports upon an approximately equal number of males and females, made by about the same number of observers of each sex. Yet it would be quite as unfair to assume that there is no basis in fact for the differences here indicated.

Warner, in his studies of London school children, previously referred to, found that 8.27 of the physical anomalies belonged to boys, while 6.78 belonged to girls. Newsholme found that males outnumber the females in still-births and attributes it to the greater difficulty in child-birth. His statistics show that for the ten years between 1865 and 1875 there were for every I00 female still-births, in France, 144 of males; in Italy, 140; in Belgium, 135; Sweden, 133 ; and in Russia, 129.

The conclusion is still further strengthened by the fact that girls appear to be favored in the transmission of desirable traits, while boys slightly preponderate in the case of undesirable ones. Boys seem to suffer more as a result of embryonic disturbances, to be in closer touch with environment, to be more readily responsible to its modifying influences, hence the very 
much greater proportion of boys than of girls, elsewhere shown, to have deformities. The tendency to variation is much more pronounced in the male.

Nationality. There is a much greater proportion of children of non-American parentage among the defective than among others-children resulting from marriages between different nationalities being especially liable to defects.

This might be the result of one, or both, of two causes. Either the children of American parentage are especially favored, or those of other nationalities come from parentage which is in most cases below the average in development. There seems to be good reason for assuming that both statemeuts are in a measure true, but the latter especially. Dr. S. P. Bowditch concluded, after the examination of many thousand school children of Boston, that children born of American parentage are both taller and heavier than those of parents of other nationalties. This difference, he thinks, is due partly to the greater degree of comfort which characterizes the bringing up of such children, and partly to difference of race.

Temperament. In a general way there appears to be agreement between temperamental conditions and health. The sanguine and cheerful are much more common in group I, while the opposite characteristics are more frequently observed in group 3 .

\section{Phdagogical Sugghstions.}

It is usually true that the treatment described shows a great want of appreciation for the individual and peculiar. There is general assertion that a thorough and special study of each individual concerned, is necessary to right treatment. This generally acknowledged need for a better understanding of individuality is reinforced most emphatically by the whole study. The most striking thing in the reports is the pronounced recognition of individual differences. This is in harmony with what scientific studies in the laboratory have shown in numerous ways, that there are many respects in which any individual differs from another.

This aspect of mind, the right appreciation of which is so vitally important to sound pedagogy, has been very far from having the attention which it requires. Individual psychology has been entirely too much neglected. The peculiar and exceptional need far more attention. From a want of this attention individuality is constantly being misunderstood. A human life is entirely too complex and unique to be estimated and understood by the application of a few principles of general psychology. Scores of teachers have begun to realize this for the first time when standing confused and helpless before a room 
full of rebellious children. With what cost the lesson is thus learned, those who have had the experience can best judge. Let it not be understood, however, that this reflects on the value and need of an equally appreciative knowledge of general psychology. But the need has not been so fully met for individual psychology.

It is a valid criticism of modern educational methods, that they have been far too little influenced by the individual basis of mind. ${ }^{1}$ Whether it be true or not, as is sometimes said, that no two leaves nor two blades of grass are exactly alike, there can be no doubt that no two persons in the world are now, or ever have been, exactly alike. However close the resemblance between them, each one has some characteristic marking his individuality which distinguishes him from every one else, and which affects the course of his destiny. By the circumstances of life the development of this intrinsic quality may be checked in one direction or fostered in another direction, but it can never be got rid of ; it is always there, a leaven leavening the whole lump. . . . . The two twin sisters of Hungary, who were united by the bottom of their backs and had the same blood, were of extremely different temperaments, and the last years of the Siamese Twins were made miserable by the quarrels arising from the different tastes of the brothers, and the different views which they took of the American Civil War."

No other question in pedagogy manifests such a crying need for intelligent, sympathetic, patient study. Scores of thousands could testify to the truth of this out of their own bitter, even tragic experiences. Many are they who have been needlessly, almost criminally misunderstood, by those from whom they had a natural right to be properly appreciated. The easy disregard with which this right is so often overridden in the name of method, system or discipline, suggests the influence of brutality, rather than that of science. The mental suffering and anguish which defectives of the various classes are compelled to endure as a result of the stares and low curiosity of others, is barbarous. The undue and excessive regard bestowed on those of the opposite kind is scarcely less disastrous in its effects, even though it is personally agreable to the subject. In the first we find timidity, irritability, morbidity, spitefulness, resentment, cunning, deceit, in fact about every form of malevolence resulting from a contracted personality. The individuality is turned back on itself, like an ingrown nail, to disturb and irritate. This is the natural result of being "laughed at," "ridiculed," " discriminated against," "run over," " scorned," "stared at," "made fun of," " kept

"Maudsley, "Pathology of Mind," p. 87. 
at home," "teased," "worried," "left out of games," "shunned," " discouraged," "scoffed at," etc.

In the second we find vanity, pride, self-esteem, over-confidence, daring, self-assertion, and the many other qualities belonging to exaggerated personalities. These are characteristics of those who are "petted," "encouraged," "adored," "'worshipped," "respected," " shown off," "looked up to," " chosen," "indulged," etc. In both, the results are equally abnormal. In the first we have delayed and retarded individualities. In the second, as a result of over stimulation, precocious and exaggerated ones.

The organization incident to mass teaching is no doubt responsible to a considerable degree for the failure to give the individual side of mind sufficient attention, but another important factor is the emphasis placed upon the common qualities of mind by much of the so-called educational psychology. Every child has a divine right to be understood as an individual, to have his peculiarities discovered, respected, appreciated, and wisely and sympathetically dealt with. This individual quality is the most precious part of the capital with which he begins life, - the very basis of all his future mental evolution. The attempts to make it comform to the conventional standard too often result in the destruction of selfhood. While too young to understand or help himself, the child is plundered of his most valuable possessions. When old enough to appreciate in a measure his condition, to assume partial self-direction, he finds bis estate loaded down with incumbrances through the carelessness of bis guardians.

The writer is indebted to Drs. Hall and Burnham for many valuable criticisms and suggestions made during the progress of this study.

ERratA.-P. 4, line 1 , large type, read $I, 001$ instead of 1,045 .

P. 4, 2d paragraph, large type, line $I$, read 583 instead of $6 r_{3}$; in line 2 read 418 instead of 432 , and $1, \infty$ r instead of $r, 045$.

\section{BIBI.IOGRAPHY.}

Af,DRICh, AuneTia Roys. Children, Their Models and Critics. New York, 1893 .

Brill, Alexanjer Graham. Memoir Upon the Formation of a Deaf Variety of the Human Race. Washington, 1884. Re-printed, pp. 4I-48, Vol. I, Am. Anuals of the Deaf.

Bovd, A. K. H. Concerning the Sorrows of Childhood. A t. Mo., Vol. IX. Brooks, W. K. Heredity. Baltimore, $188_{3}$

Bateman, Sir Fredrick, M. D. The Idiot; His Place in Creation. London, 1882 
Bateson, Wrilram. Materials for the Study of Variation. London 1894.

BowdiTch, H. P. Growth of Children, Boston, r894.

Bowdrch, H. P. Relation Between Growtll and Disease. Boston, I88I.

Clouston, T. S. The Neuroses of Development. London, i8gr.

Cope, E. D. Primary Factors of Organic Evolution. Chicago, 1896.

Dalingagne, J. Dégénérés et dés î́quilibrés. Paris, 1893.

DHLAGE, Yves. L'Hérédité. Paris, r895.

DHLAND, MARgarit. The Story of a Child. Boston, I892.

Donaldson, H. H. Growth of the Brain. New York, 1895 .

Dubors, Patrerson. Beckonings From Little Hands. Philadelphia, 1895 .

Baunes, M. Guyor. Variations in Human Stature. Pop. Sci. Mo., Vol. XXXI.

Eillis, Haverock. The Criminal. New York, r8go.

Eмminghaus, $H$. Die psychischen Storungen des Kindesalters. Tübingen, 1887 .

FARR, Will, TaM. Vital Statistics. Londou, 1885 .

Fax, Edward Aline. Marriage of the Deaf in America.

American Annals of the Deaf, Jan., Feb., April avd June, 1896. Washington.

Férź, M. Ch. La Famille Neuropathique. Paris, I894.

Fríre, M. Cr. Morbid Heredity. Pop. Sci. Mo., July, I895.

FERRERo, G, Arrested Mentation. Monist, Vol. IV., No. I.

Flower, W. H. Fashion in Deformity. Pop. Sci. Mo., XVII, 721.

Galton, Francis. Hereditary Genius. London, 1871 .

Galton, Francis. English Men of Science. London, 1874.

Gatton, Francis. Natural Inheritance. London, I889.

Guyau, M. Éducation et Hérédité. Paris, 1890 .

HAY, G. Glasgow's Bandy-Legged Children. Pop. Sci. Mo., Vol. XXV.

Hofpmaister, G. B. Race Influence and Disease. Pop. Sci. Mo., Vol. XXXVIII.

HuLd, Florenck. Preparation for Motherhood. Childhood, Dec., 1892 and Nov., 1893 .

Huxley, T. H. On the Natural Inequalities of Men. Pop. Sci. Mo., April, 1890.

Jordan, WM. Grorge. Gellius-The Model for Educational Methods. New Science Review, April, 1895 .

Közl,E, J. F. G. Die Pädagogische Pathologie in der Erziehungskunde des 19 ten Jalirhunderts. Gitersloh, I 893 .

KUHFI,ER. Pourquoi Ressemblon Nous a nos Parents? Revue Philosophique, I8th year, No. 4 .

Lombroso. Mau of Genius. Yaris, r889. New York, 1892.

I,LFHNGWELI, AIBERT. Illegitimacy and the Influence of Seasons upon Conduct. London, i892.

Legrain, M. Hérédité et Acoholisme. Paris, 1889.

Maunsy.ty, Henry. The Pathology of Mind. London, I879. 
NEwSHOLMR, ARThUR. Vital Statistics. London, 1889.

NISBET, J. F. Marriage and Heredity. London, 1889.

Nordat, Max. Degeneration. London, 1893.

OrCBansky, J. Studies on Heredity. St. Petersburg, I894.

PrRrins, F. B Childhood; A Study. At. Mo., Vol. XVIII.

Porter, WIIIIAM Townsend. Growth of St. Louis Children. Transactions of the Academy of Science, St. Louis, I894.

PorTir, Wiritam Townsend. The Relation Between the Growth of Childrea and their Deviation from the Physical Type of their Sex and Age. St. Louis, 1893.

Porter, Wirlilam Townsend. Physical Basis of Precocity and Dullness. St. Louis, 1893 .

RoBnkts, C. Bodily Deformities in Girlhood. Pop. Sci. Mo., Vol. XXII.

Russral,. E. H. Exceptional Children in School. Educational Review, Vol. VI.

SeAYEx, W. A. Giants aud Dwarfs. Harper's, XXXIX.

Singur, E. Pre-uatal and Infantile Culture. Pop. Sci. Mo., Vol. X.

SEIGLRT, G. Problematische Kindernaturen. Leipzig, I889.

Shutrumorth, G. E. Mentally Deficient Children. London, 1895.

STomLER, J Amzs H. Human Heredity. Pop. Sci. Mo., Jnly, I8go.

Strohan, S. A. K. Marriage and Disease. New York, 1892.

Strumpeld. Pädagogische Pathologie. Leipzig, 189o.

TAYtor, Miss. The Show Child. Longman's Magazine, Dec. 1895.

Thaxtar, C. Child Life at the Isle of Shorls. At. Mo., Vol. XXXI.

TUkewgl,., GrRTrudF M. The State and Its Children. London, 1894.

TRACY, F. M. Psychology of Childhood. Boston, 1893.

Warnir, Frascis. Mental Faculty. London, 1890.

WrgGrNs, Kate DOUGLas. Children's Rights. Boston, 1892.

WILDER, At,EXANDER. The Life of the Unborn Child. Childhood, Feb., 1893 .

Wilder, Alaxandrr. The Influence of the Parenta' Age upon Offspring. Childhood, Jan., 1894.

Wili,iams. Job. Hereditary Deafness-A Study. Science, Vol. XVII.

Youmans, W. J. Concerning Corpulence. Pop. Sci. Mo., I: 45I.

De l'Hérédité des Anomalies. Bulletins de la Société d'Anthropologic. Tome II.

Die Kinderfehler. J. Truper, et al. Langensalza.

Extremes of Humanity. Chambers Journal, Vol. LXVI.

Giantology. All the Year Round, Vol. IXXVI.

The Deformed and their Mental Characteristics. Littell's Liv. Age, Vol. LXXIY.

The Relations of Marriages of Consanguinity to Mental Uusoundness. Journal of Mental Science, Oct., 1886. 